\title{
Mixing state of refractory black carbon aerosol in the South Asian outflow over the northern Indian Ocean during winter
}

\author{
Sobhan Kumar Kompalli ${ }^{1}$, Surendran Nair Suresh Babu ${ }^{1}$, Krishnaswamy Krishna Moorthy ${ }^{2}$, \\ Sreedharan Krishnakumari Satheesh ${ }^{2,3,5}$, Mukunda Madhab Gogoi ${ }^{1}$, Vijayakumar S. Nair ${ }^{1}$, \\ Venugopalan Nair Jayachandran ${ }^{1}$, Dantong Liu ${ }^{4, a}$, Michael J. Flynn ${ }^{4}$, and Hugh Coe \\ ${ }^{1}$ Space Physics Laboratory, Vikram Sarabhai Space Centre, Thiruvananthapuram, India \\ ${ }^{2}$ Centre for Atmospheric \& Oceanic Sciences, Indian Institute of Science, Bengaluru, India \\ ${ }^{3}$ Divecha Centre for Climate Change, Indian Institute of Science, Bengaluru, India \\ ${ }^{4}$ Centre for Atmospheric Science, School of Earth and Environmental Sciences, University of Manchester, Manchester, UK \\ ${ }^{5}$ DST-Centre of Excellence in Climate Change, Indian Institute of Science, Bengaluru, India \\ ${ }^{a}$ now at: Department of Atmospheric Sciences, School of Earth Sciences, Zhejiang University, Hangzhou, Zhejiang, China
}

Correspondence: Surendran Nair Suresh Babu (sureshsplvssc@ gmail.com)

and Sobhan Kumar Kompalli (sobhanspl@gmail.com)

Received: 9 August 2020 - Discussion started: 1 October 2020

Revised: 14 April 2021 - Accepted: 21 April 2021 - Published: 16 June 2021

\begin{abstract}
Regional climatic implications of aerosol black carbon (BC), which has a wide variety of anthropogenic sources in large abundance, are well recognized over South Asia. Significant uncertainties remain in its quantification due to a lack of sufficient information on the microphysical properties (its concentration, size, and mixing state with other aerosol components) that determine the absorption potential of BC. In particular, the information on the mixing state of BC is extremely sparse over this region. In this study, the first observations of the size distribution and mixing state of individual refractory black carbon ( $\mathrm{rBC}$ ) particles in the South Asian outflow to the south-eastern Arabian Sea and the northern and equatorial Indian Ocean regions are presented based on measurements using a single particle soot photometer (SP2) aboard the Integrated Campaign for Aerosols, gases, and Radiation Budget (ICARB-2018) ship during winter 2018 (16 January to 13 February). The results revealed significant spatial heterogeneity of $\mathrm{BC}$ characteristics. The highest $\mathrm{rBC}$ mass concentrations $\left(\sim 938 \pm 293 \mathrm{ng} \mathrm{m}^{-3}\right)$ with the highest relative coating thickness (RCT; the ratio of BC core to its coating diameters) of $\sim 2.16 \pm 0.19$ are found over the south-east Arabian Sea (SEAS) region, which is in the proximity of the continental outflow. As we move to farther oceanic regions, though the mass concentrations decreased by nearly half $\left(\sim 546 \pm 80 \mathrm{ng} \mathrm{m}^{-3}\right)$, BC still re-
\end{abstract}

mained thickly coated $(\mathrm{RCT} \sim 2.05 \pm 0.07)$. The air over the remote equatorial Indian Ocean, which received considerable marine air masses compared to the other regions, showed the lowest $\mathrm{rBC}$ mass concentrations $\left(\sim 206 \pm 114 \mathrm{ng} \mathrm{m}^{-3}\right)$ with a moderately thick coating $(\mathrm{RCT} \sim 1.73 \pm 0.16)$. Even over oceanic regions far from the landmass, regions that received the outflow from the more industrialized east coast/the Bay of Bengal had a thicker coating $(\sim 104 \mathrm{~nm})$ compared to regions that received outflow from the west coast and/or peninsular India $(\sim 86 \mathrm{~nm})$. Although different regions of the ocean depicted contrasting concentrations and mixing state parameters due to the varied extent and nature of the continental outflow as well as the atmospheric lifetime of air masses, the modal parameters of rBC mass-size distributions (mean mass median diameters $\sim 0.19-0.20 \mu \mathrm{m}$ ) were similar over all regions. The mean fraction of BC-containing particles $\left(F_{\mathrm{BC}}\right)$ varied in the range of 0.08-0.12 (suggesting significant amounts of non-BC particles), whereas the bulk mixing ratio of coating mass to $\mathrm{rBC}$ mass was highest $(8.31 \pm 2.40)$ over the outflow regions compared to the remote ocean $(4.24 \pm 1.45)$, highlighting the role of outflow in providing condensable material for coatings on $\mathrm{rBC}$. These parameters, along with the information on the sizeresolved mixing state of $\mathrm{BC}$ cores, throw light on the role of sources and secondary processing of their complex mixtures 
for coatings on BC under highly polluted conditions. Examination of the non-refractory sub-micrometre aerosol chemical composition obtained using the aerosol chemical speciation monitor (ACSM) suggested that the overall aerosol system was sulfate-dominated over the far-oceanic regions. In contrast, organics were equally prominent adjacent to the coastal landmass. An association between the $\mathrm{BC}$ mixing state and aerosol chemical composition suggested that sulfate was the probable dominant coating material on rBC cores.

\section{Introduction}

Black carbon (BC) is the dominant light-absorbing atmospheric aerosol species that perturbs regional and global radiation balance through the positive radiative forcing arising out of its strong absorption of solar radiation and its ability to reduce cloud albedo (Menon et al., 2002; Ramanathan and Carmichael, 2008; IPCC, 2013; Bond et al., 2013; Huang et al., 2016). Produced by the incomplete combustion of hydrocarbon fuels, $\mathrm{BC}$ has a global direct radiative forcing of $+0.71 \mathrm{~W} \mathrm{~m}^{-2}\left(+0.08\right.$ to $\left.+1.26 \mathrm{~W} \mathrm{~m}^{-2}\right)$, of which fossil fuel and biofuel emissions contribute $+0.51 \mathrm{~W} \mathrm{~m}^{-2}$; the rest is from biomass burning (Bond et al., 2013). Such large forcing due to $\mathrm{BC}$ is reported to be capable of causing significant perturbations to atmospheric circulation, cloud dynamics, rainfall pattern, static stability, and convective activity over regional scales, especially over the Indian region (Menon et al., 2002; Ramanathan et al., 2005; Meehl et al., 2008; Bollasina et al., 2008; Lawrence and Lelieveld, 2010; Babu et al., 2011; D'Errico et al., 2015; Boos and Storelvmo, 2016). While fresh BC is fractal-like, hydrophobic, and externally mixed, atmospheric ageing (temporally and/or chemically) results in internally mixed $\mathrm{BC}$ with hydrophilic compounds (e.g., organic acids and ammonium sulfate) and an altered mixing state, size, and morphology. Also, the ageing process leads to enhanced absorption potential of BC (Schnaiter et al., 2005; Shiraiwa et al., 2010; Cappa et al., 2012, 2019; Zhang et al., 2015; Peng et al., 2016; Ueda et al., 2016). The mixing state of $\mathrm{BC}$ is a vital parameter that determines its optical and radiative properties (Moffet and Prather, 2009; Liu et al., 2017) and is a critical input parameter for the models used to estimate $\mathrm{BC}$ direct radiative forcing (Bond et al., 2013). The information on the nature of the coating material along with the state of mixing of $\mathrm{BC}$ particles gives insight into the magnitude of the mixing-induced absorption enhancement for BC (Cappa et al., 2012, 2019; Peng et al., 2016; Liu et al., 2017). Further, the coating of other soluble species on BC modifies its hygroscopicity and cloud condensation nuclei (CCN) activity (McMeeking et al., 2011; Liu et al., 2013; Laborde et al., 2013) and, therefore, the mixing state alters BC-induced cloud changes and indirect radiative effects. Thus, the characterization of $\mathrm{BC}$ size and its mixing state is critical to reducing the uncertainties in its direct and indirect radiative effects (Jacobson, 2001; Bond et al., 2013).

The BC sources are highly varied, both seasonally and spatially, over the Indian region (e.g., Kompalli et al., 2014a; Prasad et al., 2018, and references therein). Aerosol BC has an average atmospheric lifetime of about a week (Lund et al., 2018; Bond et al., 2013). It is prone to regional as well as long-range transport during its short atmospheric lifetime and found even over remote regions, such as the polar regions, albeit in lower concentrations (Raatikainen et al., 2015; Liu et al., 2015; Sharma et al., 2017; Zanatta et al., 2018). The alteration to BC mixing state depends on various factors, which include the $\mathrm{BC}$ size distribution, nature of sources, the concentration of condensable materials that BC encounters during its atmospheric lifetime, and processes such as photochemical ageing (Liu et al., 2013; Ueda et al., 2016; Miyakawa et al., 2017; Wang et al., 2018). Consequently, the nature and extent of coating on $\mathrm{BC}$ vary in space and time and, as such, BC in a polluted environment chemically ages faster than in a relatively clean environment (e.g., Peng et al., 2016; Liu et al., 2010, 2019; Cappa et al., 2019). This calls for region-specific characterization of the spatiotemporal variability of the $\mathrm{BC}$ mixing state. This is particularly important over the South Asian region (with rapidly increasing anthropogenic activities and enhanced emissions from a variety of sources) and its outflow into the adjoining oceans (Lawrence and Lelieveld, 2010; Babu et al., 2013; IPCC, 2013). Aerosol BC over this region has a wide variety of sources (industrial and vehicular emissions, biomass, crop residue, and residential fuel burning) and is co-emitted with a broad spectrum of gaseous compounds that form secondary aerosol species such as sulfates, nitrates, phosphates, and secondary organic aerosols (SOAs) (Gustafsson et al., 2009; Pandey et al., 2014) leading to complex mixing states of BC during its atmospheric chemical ageing. The absorption potential of the resultant mixed-phase particles would be quite different from those of nascent BC (Lawrence and Lelieveld, 2010; Srivastava and Ramachandran, 2013; Srinivas and Sarin, 2014; Moorthy et al., 2016). When air masses from such complex source regions are transported to remote regions devoid of any sources of $\mathrm{BC}$, the mixing state of $\mathrm{BC}$ may change. This is due to (a) the restructuring of the $\mathrm{BC}$ aggregates during the transport due to different processes (Kütz and Schmidt-Ott, 1992; Weingartner et al., 1995; Slowik et al., 2007b; Pagels et al., 2009) and (b) the varied nature and amounts of coating material arising due to the different atmospheric lifetimes and microphysical processes involving different species (McFiggans et al., 2015). Therefore, the characterization of aerosol and trace species properties has gained much attention over the years. Lawrence and Lelieveld (2010) have highlighted many field experiments that attempted to assess the impact of continental outflow of anthropogenic emissions from South Asia to the surrounding oceanic regions and its climate implications. Past field campaigns, such as the Indian Ocean Experiment (INDOEX) 
during 1998-1999 (Ramanathan et al., 2001) and the Integrated Campaign for Aerosols, gases, and Radiation Budget (ICARB) during March-May 2006 (phase 1) and DecemberJanuary 2008/09 (phase 2) (Moorthy et al., 2008; Babu et al., 2012; Kompalli et al., 2013), have characterized regional aerosols over the northern Indian Ocean during different seasons.

However, the information on BC microphysical properties (especially its size distribution, mixing state, and extent of coating) over the northern Indian Ocean has remained elusive primarily due to a lack of instruments for near realtime measurements to estimate BC size and coating (Kompalli et al., 2020b). A combination of analytical instruments, such as the single particle soot photometer (SP2) based on the laser-induced incandescence technique for the measurements of microphysical properties of refractory $\mathrm{BC}(\mathrm{rBC})$ at a single particle level (Moteki and Kondo, 2007; Schwarz et al., 2008, 2013; Laborde et al., 2012; Liu et al., 2014), the mass spectroscopy-based aerosol chemical composition measurements (Liu et al., 2014; Gong et al., 2016) such as the aerosol mass spectrometer (AMS) (Jayne et al., 2000; Jimenez et al., 2003; Allan et al., 2003), or the aerosol chemical speciation monitor (ACSM) (Ng et al., 2011) that provide near real-time information on the possible coating substances, provides a way to address this issue (Kompalli et al., 2020b, and references therein).

In this study, we report the first measurements of BC microphysical properties over the south-eastern Arabian Sea and the northern and equatorial Indian Ocean regions. The observations were carried out as a part of the third phase of the Integrated Campaign for Aerosols, gases, and Radiation Budget (ICARB) campaign during the winter season when the abovementioned oceanic regions are strongly impacted by the South Asian outflow aided by the favourable synoptic winds (Lawrence and Lelieveld, 2010; Nair et al., 2020). The weak winds and absence of strong precipitation during this season are conducive to longer atmospheric lifetimes and support inter-hemispheric transport of the pollutants. The main aims of our measurements included: (i) characterization of the spatio-temporal variation of $\mathrm{BC}$ size distributions over the northern Indian Ocean, (ii) examination of the extent of $\mathrm{BC}$ transport from distinct source regions and changes to its mixing state during the transport to the ocean, and (iii) quantification of the degree of coating on $\mathrm{BC}$ and identification of the nature of potential coating species by using concurrent chemical composition measurements during the South Asian outflow. The results of the campaign are presented and implications discussed.

\section{Experimental measurements}

\subsection{Campaign details and meteorology}

Phase 3 of the Integrated Campaign for Aerosols, gases, and Radiation Budget cruise-based experiment (hereafter referred to as the ICARB-2018) was carried out during the winter period (16 January-13 February 2018) along the track shown by the solid black line in Fig. 1, covering different parts of the south-eastern Arabian Sea (SEAS), the northern Indian Ocean (NIO), and the equatorial Indian Ocean (EIO), as highlighted by the different boxes about the track. More details about the experiment and sampling conditions are available in earlier publications (Gogoi et al., 2019; Nair et al., 2020; Kompalli et al., 2020a). Briefly, the measurements were made from the specially configured aerosol laboratory on the top deck of the ship, $\sim 15 \mathrm{~m}$ above the sea level, and the instruments sampled air from a community aerosol inlet set up with an upper size cut-off at $10 \mu \mathrm{m}$ at a flow rate of 16.67 litres per minute (LPM). Membrane-based dryers were installed in the sampling lines to remove the excess moisture (to limit the sampling relative humidity (RH) to $<40 \%$ ). Proper care was taken to avoid contamination from the ship's emissions by aligning the bow of the ship against the wind direction, and any spurious data were removed during post-processing (as has been done in earlier such campaigns; Moorthy et al., 2008).

The South Asian region is known for its seasonally contrasting synoptic meteorology associated with the Asian monsoon and north-south excursion of the inter-tropical convergence zone (ITCZ) and monsoonal circulations (Das, 1986; Asnani, 1993). During the winter (December to February), calm north-easterly winds prevail over the Indian landmass, which facilitates extensive transport of continental air mass to the surrounding ocean. The synoptic conditions during the campaign period were quite similar to the climatological pattern, as revealed by Fig. S1a in the Supplement, which shows the prevailing synoptic mean wind vectors at $925 \mathrm{hPa}$ derived from ERA-Interim wind data from ECMWF (European Centre for Medium range Weather Forecasting; https://apps.ecmwf.int/datasets/ data/interim-full-daily/levtype $=$ sfc/, last access: 25 February 2020) data. The spatial distribution of fire counts over the continental landmass lying upwind of the campaign area, as derived from the Moderate Resolution Imaging Spectroradiometer (MODIS) fire radiative power (MODIS Thermal Anomalies/Fire locations, Collection 6 product obtained from https://earthdata.nasa.gov/firms, last access: 24 February 2020) for the period 10 January to 14 February 2018, is shown Fig. S1b in the Supplement. It reveals a significant number of fire events in the upwind regions. Monthly mean tropospheric $\mathrm{NO}_{2}$ column abundances obtained from TROPOspheric Monitoring Instrument (TROPOMI) (http://www. temis.nl/airpollution/no2col/no2regio_tropomi.php, last access: 27 February 2020) data, shown in the bottom panels 


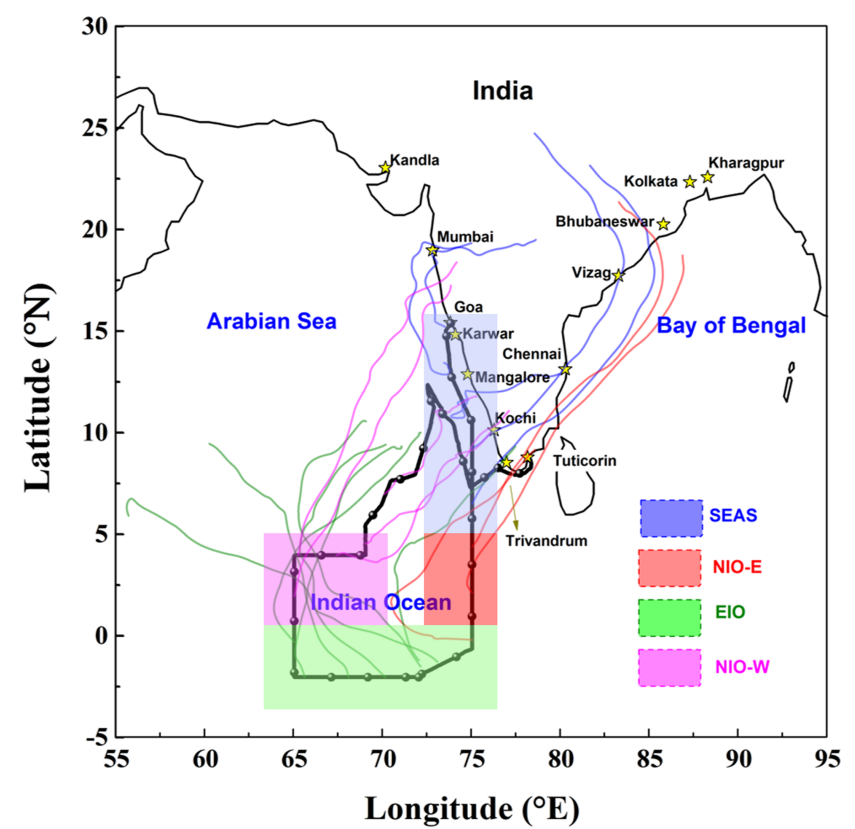

Figure 1. Cruise track of the ICARB-2018 over the northern Indian Ocean from 16 January to 13 February 2018; the different classified sub-regions are highlighted with shaded portions, and major industrial cities and ports along with coastline are marked with a star symbol. HYSPLIT $5 \mathrm{~d}$ isentropic air mass back trajectories arriving at $100 \mathrm{~m}$ a.m.s.l. (dashed lines) above the ship location at 05:30 UTC on each day for different sub-regions are shown in different colours. The filled circles on the track indicate the daily mean position of the ship. SEAS: south-east Arabian Sea; NIO-E: northern Indian Ocean-east; EIO: equatorial Indian Ocean; NIO-W: northern Indian Ocean-west; southern Arabian Sea: SAS; this region was affected by rain and a large scale meteorological system. The data from the SAS were not included in the overall analysis.

of the same figure (for January 2018 see Fig. S1c and for February 2018 see Fig. S1d in the Supplement), show significant emissions over the continental areas upwind, a part of which would be transported to the oceanic regions during the ICARB-2018. Earlier, based on the observations using the optical attenuation technique (aethalometer) over the upwind locations (Kharagpur, Bhubaneswar, Vizag, Trivandrum), Kompalli et al. $(2013,2014 \mathrm{~b})$ reported that the highest equivalent black carbon (EBC; optically measured BC) mass concentrations throughout the year are seen during the winter period (mean values ranging from $\sim 5389 \pm 1245 \mathrm{ng} \mathrm{m}^{-3}$ over Trivandrum to $11691 \pm 4457 \mathrm{ng} \mathrm{m}^{-3}$ over Kharagpur), which highlighted the source strength during this season. Also, the east coast of India is more industrialized compared to the west coast and/or peninsular India (Fig. S1c and d in the Supplement; Moorthy et al., 2005; Kompalli et al., 2013).

Air mass back trajectories derived using the Hybrid Single-Particle Lagrangian Integrated Trajectory (HYSPLIT) (https://www.arl.noaa.gov/hysplit/ready/, last access: 20 September 2019) and shown in Fig. 1 highlight the po- tential long-range transport of the continental emissions to different oceanic regions covered during the campaign. Accordingly, the cruise region is divided into five distinct subregions: (i) south-eastern Arabian Sea (SEAS), which encountered direct outflow from the strong source regions in the western coastal and peninsular India region (shown with a blue box and air mass trajectories); (ii) northern Indian Ocean-east (NIO-E) (eastern leg of the cruise covering the NIO region) that experienced air masses from the east coast of India and the Bay of Bengal regions (red); (iii) equatorial Indian Ocean (EIO), where mostly marine air masses originated and/or confined within the north-eastern Arabian Sea and without any direct influence of continental outflow (green); (iv) northern Indian Ocean-west (NIO-W), which experiences outflow mainly from western coastal regions of Peninsular India after considerable transit over the Sea (magenta); and (v) southern Arabian Sea (SAS), the unshaded region of the track where widespread rainfall associated with the passage of a large scale meteorological system was encountered. We have not included the data collected over the SAS region in the overall analysis of the present study, and a brief discussion about it is provided in the Supplement. During the rest of the cruise period, calm winds $\left(<5 \mathrm{~m} \mathrm{~s}^{-1}\right)$ and clear sky conditions prevailed with no significant variation in air temperature (mean $\sim 28 \pm 0.8^{\circ} \mathrm{C}$ ) and relative humidity (mean $\sim 73 \pm 5 \%$ ) conditions. Table 1 gives the details of the regional mean (avg), maximum (max) and minimum (min) values of meteorological variables (air temperature (AT), relative humidity (RH), wind speed (WS), wind direction (WD), total accumulated rainfall (RF) amount) for different regions covered during the ICARB-2018.

\subsection{Measurements}

Of the several measurements made, the measurements of the $\mathrm{BC}$ single particle microphysical properties were carried out using a single-particle soot photometer (SP2) (Model: SP2-D; Droplet Measurement Technologies, Boulder, USA), which was operated at a flow rate of $0.08 \mathrm{~L} \mathrm{~min}^{-1}$. The SP2 employs a $1064 \mathrm{~nm}$ Nd:YAG intracavity laser and by using a laser-induced incandescence technique, it characterizes the physical properties of refractory $\mathrm{BC}(\mathrm{rBC})$ at the individual particle level (Moteki and Kondo, 2007; Schwarz et al., 2008, 2013; Laborde et al., 2012; Liu et al., 2014; Shiraiwa et al., 2007; Kompalli et al., 2020b). It provides information about mass and number concentrations and size distributions of $\mathrm{rBC}$. The amplitude of the incandescence signal is proportional to the $\mathrm{rBC}$ mass present in the $\mathrm{BC}$-containing particles, and the mass equivalent diameter (the diameter of a sphere containing the same mass of $\mathrm{rBC}$ as measured), or $\mathrm{BC}$ core diameter $\left(D_{\mathrm{c}}\right)$, is obtained from the measured $\mathrm{rBC}$ mass by assuming a density, $\rho \sim 1.8 \mathrm{~g} \mathrm{~cm}^{-3}$, for atmospheric BC (Bond and Bergstrom, 2006; Moteki and Kondo, 2007, 2010; McMeeking et al., 2011). Further, the amplitude of the scattering signal provides information about the scattering cross 
Table 1. Regional values of meteorological parameters observed during the cruise period.

\begin{tabular}{|c|c|c|c|c|c|c|c|c|c|c|c|}
\hline \multirow[t]{2}{*}{ Region } & \multicolumn{3}{|c|}{ AT $\left({ }^{\circ} \mathrm{C}\right)$} & \multicolumn{3}{|c|}{ RH (\%) } & \multicolumn{3}{|c|}{$\mathrm{WS}\left(\mathrm{m} \mathrm{s}^{-1}\right)$} & \multirow[t]{2}{*}{$\mathrm{WD}\left(^{\circ}\right)$} & \multirow[t]{2}{*}{$\mathrm{RF}(\mathrm{mm})$} \\
\hline & Avg & Max & Min & Avg & Max & Min & Avg & Max & Min & & \\
\hline SEAS & 27.6 & 29.3 & 26.8 & 76.2 & 86.3 & 65.9 & 2.7 & 5.5 & 0.3 & NE & 0 \\
\hline NIO-E & 28.0 & 28.7 & 27.0 & 69.0 & 76.5 & 60.1 & 3.1 & 4.8 & 2.0 & $\mathrm{NE}$ & 0 \\
\hline EIO & 28.0 & 29.1 & 26.9 & 72.2 & 79.4 & 65.5 & 4.7 & 8.8 & 2.3 & NW & 0 \\
\hline NIO-W & 28.4 & 28.9 & 27.7 & 72.7 & 78.5 & 66.1 & 4.2 & 6.2 & 1.7 & NW & 7.1 \\
\hline SAS & 28.2 & 30.0 & 27.4 & 73.9 & 81.9 & 61.1 & 2.8 & 5.7 & 0.1 & $\mathrm{~N}$ & 50.5 \\
\hline
\end{tabular}

section of the particles, which is used to determine the optical sizing of the particles. In the case of BC-containing particles, the scattering signal gets distorted as it passes through the laser beam because of the intense thermal heating of the particle and evaporation of the coating. Thus, the scattering signal of the $\mathrm{BC}$ particle is reconstructed using a leading-edge only (LEO) fitting technique, as described in earlier publications (Gao et al., 2007; Liu et al., 2010, 2014, 2017), and this scattering cross section is matched with the modelled values in a Mie lookup table to derive the optical diameter of a $\mathrm{BC}$ particle or the coated $\mathrm{BC}$ size $\left(D_{\mathrm{p}}\right)$. Here, the total particle is treated as an ideal two-component sphere with a concentric core-shell morphology, with a core $(\mathrm{rBC})$ refractive index value of 2.26-1.26i (Moteki et al., 2010; Liu et al., 2014; Taylor et al., 2015) and a coating refractive index of $1.5+0 i$ (which is an optimum value and in the range of refractive indices of inorganic salts $\left(\left(\mathrm{NH}_{4}\right)_{2} \mathrm{SO}_{4}=1.51\right.$; $\mathrm{NaCl}=1.53)$ and secondary organic aerosols $(\sim 1.44-1.5)$ at $\lambda=1064 \mathrm{~nm}$ (Schnaiter et al., 2005; Metcalf et al., 2012; Lambe et al., 2013; Laborde et al., 2013; Taylor et al., 2015). These two diameters $\left(D_{\mathrm{p}}\right.$ and $D_{\mathrm{c}}$ ) are used to infer the coating thickness. Before the experiment, the SP2 was calibrated using Aquadag ${ }^{\circledR}$ black carbon particle standards (Aqueous Deflocculated Acheson Graphite, manufactured by Acheson Inc., USA), and a correction factor of 0.75 is applied to address the difference between Aquadag ${ }^{\circledR}$ standards and ambient BC (e.g., Moteki and Kondo 2010; Laborde et al., 2012). A detailed description of the instrument, data interpretation procedures, uncertainties, and caveats involved can be found elsewhere (Liu et al., 2010, 2014; McMeeking et al., 2010; Sedlacek et al., 2012, 2018; Kompalli et al., 2020b). It is recognized that the SP2 cannot provide the details of $\mathrm{rBC}$ aggregate morphology or the relative position of the $\mathrm{BC}$ within the particle, which can be determined better through microscopy-based studies (e.g., Adachi et al., 2010; Ueda et al., 2018). However, the intensity of the incandescence signal detected by the SP2 is proportional to the refractory black carbon mass present in the particle and is independent of particle morphology and mixing state (Slowik et al., 2007a; Moteki and Kondo, 2007; Schwarz et al., 2008). Again, though the SP2 has limited detection sensitivity towards pure scatterers because of the limited size range it covers, the light scattering information at $1064 \mathrm{~nm}$ has been widely used to accurately derive the size of the coated particle (Gao et al., 2007; Moteki et al., 2010; Shiraiwa et al., 2008, 2010; Laborde et al., 2013; Taylor et al., 2015; Liu et al., 2017).

Supplementing the above, we used the information on the mass concentration of non-refractory $\mathrm{PM}_{1.0}$ aerosols (organics, sulfate, ammonium, nitrate, and chloride) from a collocated aerosol chemical speciation monitor (ACSM; Model: 140; Aerodyne, USA) (Ng et al., 2011). The objective here is to identify the possible coating material on $\mathrm{rBC}$ particles. The ACSM consists of a particle sampling inlet, three vacuum chambers (differentially pumped by turbopumps, backed by the main diaphragm pump), and a residual gas analyser (RGA) mass spectrometer (Pfeiffer Vacuum $\mathrm{GmbH}$ ). The particles are drawn to an aerodynamic lens assembly having $D_{50}$ limits (50\% transmission range) of 75-650 nm and $30 \%$ to $40 \%$ transmission efficiency at $1 \mu \mathrm{m}$ (Liu et al., 2007) through a $100 \mu \mathrm{m}$ critical orifice. These particles are focused into a narrow beam and transmitted to a vacuum environment where they are flash vaporized by the thermal capture vaporizer (Xu et al., 2017; Hu et al., 2017a, b) operating at $525^{\circ} \mathrm{C}$. Subsequently, these vapours are ionized via $70 \mathrm{eV}$ electron impact ionization and detected with a quadrupole mass spectrometer. The data are processed as per the prescribed methodology ( $\mathrm{Ng}$ et al., 2011; Middlebrook et al., 2012; Kompalli et al., 2020b). We used software provided by the manufacturer (Aerodyne Research, ACSM Local, version 1.6.0.3, within IGOR Pro version 7.0.4.1) for processing and analysis of data. Using the default fragmentation table (Allan et al., 2004), the measured fractions of unit mass resolution spectra signals were apportioned to individual aerosol species. The required corrections for the instrument performance for the varied inlet pressures and $\mathrm{N}_{2}$ signal were performed (Ng et al., 2011; Sun et al., 2012). Massdependent ion transmission efficiency correction of the residual gas analyser was carried out using the signals from the internal diffuse naphthalene source $(\mathrm{m} / z$ 128). The calibrations of ionization efficiency (IE) and relative IE (RIE) calibrations were performed prior to the experiment by using monodisperse $(300 \mathrm{~nm})$ particles of $\mathrm{NH}_{4} \mathrm{NO}_{3}$ and $\left(\mathrm{NH}_{4}\right)_{2} \mathrm{SO}_{4}$ (Jayne et al., 2000; Allan et al., 2003; Jimenez et al., 2003; Canagaratna et al., 2007). The present ACSM consists of a capture vaporizer with an inner cavity to reduce the particle bounce (Xu et al., 2017), resulting in a higher collection ef- 
ficiency (about unity) (Hu et al., 2017a, b). Therefore, the composition-dependent collection efficiency correction prescribed by Middlebrook et al. (2012), applicable to standard vaporizer instruments, was not applied to our data. More than 1200 quality checked individual observations with a time resolution of $\sim 30 \mathrm{~min}$ formed the database for this study.

Continuous measurements of the particle number size distributions in the size range of 10 to $414 \mathrm{~nm}$ were also carried out aboard, at the $5 \mathrm{~min}$ interval, using a scanning mobility particle sizer spectrometer (SMPS; TSI Inc., USA) during the campaign (Kompalli et al., 2020a). The SMPS consists of an electrostatic classifier (TSI 3080), a long differential mobility analyser to size segregate the particles based on their electrical motilities (Wiedensohler, 1988) that are subsequently counted by using a water-based condensation particle counter (TSI 3786). Concurrent measurements of the particle number size distributions in the aerodynamic diameters range of 542 to $19800 \mathrm{~nm}$ (which can be converted to stokes diameters using an effective particle density) have also been made using the aerodynamic particle sizer (APS; Make: TSI, Model: 3321) that works based on the "time-of-flight" technique (Leith and Peters, 2003). Though the contribution from the particles in the sizes measured by the APS to the overall aerosol number concentrations are found to be $<2 \%$; combining both these measurements gives the total particle number concentrations covering a wide size range (10$10000 \mathrm{~nm}$ ). We have used the particle number size distributions (and total particle number concentrations) from 10$1000 \mathrm{~nm}$ from the SMPS + APS measurements, along with the number concentration of $\mathrm{rBC}$ from the SP2 to estimate the fraction of $\mathrm{rBC}$-containing particles.

\subsection{Analysis}

The extent of coating on $\mathrm{rBC}$ particles is quantified in terms of the bulk relative coating thickness (RCT) defined as $D_{\mathrm{p}} / D_{\mathrm{c}}$, where $D_{\mathrm{p}}$ and $D_{\mathrm{c}}$ are coated and core BC particle diameters, respectively. It is estimated by dividing the total volume of coated $\mathrm{BC}$ with that of $\mathrm{rBC}$ cores in a given time window (5 min in our case) following Liu et al. $(2014,2019)$ :

$$
\frac{D_{\mathrm{p}}}{D_{\mathrm{c}}}=\sqrt[3]{\frac{\sum_{i} D_{\mathrm{p}, i}^{3}}{\sum_{i} D_{\mathrm{c}, i}^{3}}},
$$

where $D_{\mathrm{p}, i}$ and $D_{\mathrm{c}, i}$ are the diameters of coated and core $\mathrm{rBC}$, respectively, for each single particle $i$. In addition to RCT, we have used bulk volume-weighted absolute coating thickness (ACT, in nm), defined as $\left(D_{\mathrm{p}}-D_{\mathrm{c}}\right) / 2$ (both $D_{\mathrm{p}}$ and $D_{\mathrm{c}}$ used here are volume averaged diameters) based on the assumption of a concentric core-shell morphology, as another diagnostic of the coating on the population of rBC particles (Gong et al., 2016; Cheng et al., 2018; Brooks et al., 2019). More details about the parameters bulk RCT and ACT, the methodology used here, and uncertainties as- sociated were described elsewhere (Liu et al., 2017, 2019; Sedlacek et al., 2018; Brooks et al., 2019; Kompalli et al., 2020b).

The means of the mass median diameter (MMD) and number median diameter (NMD) were determined from the size distributions of $\mathrm{BC}$ cores for each time window by least squares fitting to an analytical monomodal log-normal distribution (Liu et al., 2010, 2014; Kompalli et al., 2020b) of the following form:

$$
\frac{\mathrm{d} X}{\mathrm{~d} \ln D_{\mathrm{q}}}=\sum \frac{X_{0}}{\sqrt{2 \pi} \ln \sigma_{\mathrm{m}}} \exp \left[-\frac{\left(\ln D_{\mathrm{q}}-\ln D_{\mathrm{m}}\right)^{2}}{2 \ln \sigma_{\mathrm{m}}}\right] .
$$

Here $X_{0}$ corresponds to mass/number concentration of the mode, $D_{\mathrm{m}}$ is the mass/number median diameter, $D_{\mathrm{q}}$ is particle diameter, $\mathrm{d} X$ is mass/number concentrations in an infinitesimal diameter interval $\mathrm{d} \ln D_{\mathrm{q}}$, and $\sigma_{m}$ is the geometric standard deviation (of the median diameter).

Using the bulk RCT and MMD of the $\mathrm{BC}$ cores, the volume-weighted coated $\mathrm{BC}$ size $\left(D_{\mathrm{p}, \mathrm{v}}\right)$ is calculated as below to indicate the mean coated $\mathrm{BC}$ size:

$D_{\mathrm{p}, \mathrm{v}}=\frac{D_{\mathrm{p}}}{D_{\mathrm{c}}} \times \mathrm{MMD}$.

Since the ratio of the mass of non-absorbing coating material to the $\mathrm{rBC}$ core is an important parameter in determining the degree of absorption enhancement of $\mathrm{BC}$, we quantified their mixing in terms of the bulk mixing ratio of coating mass over rBC mass $\left(M_{\mathrm{R}, \text { bulk }}\right)$ derived by assuming densities for the bulk coating $\left(\rho_{\text {coating }}\right)$ and $\mathrm{rBC}$ core $\left(\rho_{\mathrm{rBC} \text { core }} \sim 1.8 \mathrm{~g} \mathrm{~cm}^{-3}\right)$ (Liu et al., 2019) as below:

$M_{\mathrm{R}, \text { bulk }}=\left(\left(\frac{D_{\mathrm{p}}}{D_{\mathrm{c}}}\right)^{3}-1\right) \times \frac{\rho_{\text {coating }}}{\rho_{\mathrm{rBC} \text { core }}}$.

Here we have used the effective dry density ( $\left.\rho_{\text {coating }}\right)$ of ambient NR-PM ${ }_{1.0}$ based on the measured near real-time chemical composition (Budisulistiorini et al., 2016) by assuming densities of organics and inorganics as 1.4 (Hallquist et al., 2009) and $1.77 \mathrm{~g} \mathrm{~cm}^{-3}$ (Park et al., 2004), respectively.

To explore the distribution of BC core-coatings, a parameter of scattering enhancement $\left(E_{\text {sca }}\right)$ for each single particle is determined using the expression (Liu et al., 2014, 2019):

$E_{\text {sca }}=\frac{S_{\text {measured,coatedBC }}}{S_{\text {calculated,uncoatedBC }}}$,

where the term in the numerator is the scattered light intensity of the coated $\mathrm{rBC}$ particle measured by the scattering detector of the SP2 and reconstructed using the LEO technique, while the denominator is the scattering intensity of the uncoated BC calculated using Mie single particle scattering solutions assuming sphericity (Liu et al., 2014, 2019; Taylor et al., 2014; Brooks et al., 2019). For this purpose, the measured $\mathrm{rBC}$ mass and a refractive index of $\mathrm{BC}$ of 
$\sim 2.26 \pm 1.26 i$ (Moteki et al., 2010) at the SP2 laser wavelength, $\sim 1064 \mathrm{~nm}$, were used. For an uncoated rBC particle, $E_{\text {sca }}$ is equal to 1 , and $E_{\text {sca }}$ increases with an increased coating at a given core size. Combined with $\mathrm{rBC}$ core diameters and coating parameters, $E_{\text {sca }}$ is helpful in identifying the nature of sources, though under the assumption that no material loss via oxidative and/or photochemistry occurs, which can either alter overall particle size and/or the refractive index of the coating.

\section{Results and discussion}

\subsection{Spatial distribution of $\mathrm{rBC}$ mass/number concentrations and size distributions}

The spatial variations of the number and mass concentrations of refractory $\mathrm{BC}$ core particles during the cruise are shown in Fig. 2, along with the statistics over different regions depicted using the box-and-whisker plots.

The highest values and variabilities (standard deviation) in the $\mathrm{rBC}$ mass (mean $\sim 938 \pm 293 \mathrm{ng} \mathrm{m}^{-3}$ ) and number $(\sim$ $378 \pm 137 \mathrm{~cm}^{-3}$ ) concentrations are noticed over the SEAS region, which is in the proximity of the source regions and/or outflow from the western coast and peninsular India, where industrialized cities and major ports are located (Figs. 1 and $\mathrm{S} 1$ in the Supplement). The concentrations decreased gradually by half as the ship headed towards the NIO-E (eastern leg of the NIO), where it received outflow mostly from the east coast and/or the Bay of Bengal regions. The lowest concentrations (which were 4-5 fold lower than the values seen over the SEAS) are observed over the remote EIO region. The lower concentrations $\left(<200 \mathrm{ng} \mathrm{m}^{-3}\right)$ highlighted the cleaner nature of this region, which encountered mostly oceanic air masses. The concentrations increased again (almost 3-fold compared to the values seen over the EIO region) as the ship traversed to the NIO-W (western leg of the NIO) region, which experienced continental outflow air masses from the west coast and/or peninsular India, similar to the SEAS but farther from the coast and SEAS region. Thus, the concentrations in the NIO-W were lower than those seen in the SEAS and comparable to those seen in its eastern counterpart (NIOE). This also indicated varied amounts of $\mathrm{BC}$ in the outflow from different parts of the peninsula, apparently due to different source strengths and transit times involved. A similar spatial variability pattern was also reported for other aerosol parameters during the present campaign (Gogoi et al., 2019; Nair et al., 2020; Kompalli et al., 2020a).

The size distributions of $\mathrm{rBC}$ are influenced by the source, sinks, and transformation processes taking place during advection and are known to be important in assessing the light absorption characteristics (Reddington et al., 2013). The MMD values of the $\mathrm{rBC}$ size distributions are strongly influenced by the source of BC emissions (e.g., Ko et al., 2020; Cheng et al., 2018). Recently, Ko et al. (2020) compared the MMD and NMD values of rBC size distributions from different dominant sources. Previous studies report that the MMD (and NMD) values over the regions dominated by fresh fossil fuel emissions are smaller (MMD 100 to $178 \mathrm{~nm}$ and NMD $\sim 30$ to $80 \mathrm{~nm}$ ) compared to the areas with dominant solid-fuel sources (biomass, biofuel, coal-burning) (MMD $\sim 130$ to $210 \mathrm{~nm}$ and NMD $\sim 100$ to $140 \mathrm{~nm}$ ), whereas well-aged and background BC particles in outflow regions have MMD values in between (MMD 180 to $225 \mathrm{~nm}$ and NMD $\sim 90$ to $120 \mathrm{~nm}$ ) (McMeeking et al., 2010; Liu et al., 2010, 2014; Kondo et al., 2011; Cappa et al., 2012; Sahu et al., 2012; Metcalf et al., 2012; Laborde et al., 2013; Reddington et al., 2013; Gong et al., 2016; Raatikainen et al., 2017; Krasowsky et al., 2018; Brooks et al., 2019; Kompalli et al., 2020b; Ko et al., 2020). The spatial distribution of mass median diameter and number median diameters during the ICARB-2018 shown in Fig. 3 was interpreted based on this backdrop. The observed mean NMD $(0.10-0.11 \mu \mathrm{m})$ and MMD $(0.19-0.20 \mu \mathrm{m})$ values over the entire study region (Fig. $3 \mathrm{c}$ and d) are within the range of values reported in earlier studies for chemically aged continental outflow and a combination of sources. Chemical ageing of $\mathrm{BC}$ is another important factor affecting the $\mathrm{rBC}$ core sizes owing to transformation processes (such as collapsing of the BC cores and/or due to coagulation) taking place during the long-range transport (Shiraiwa et al., 2008; Bond et al., 2013; Ko et al., 2020). Freshly produced BC particles comprise fractal-like aggregates of spherical graphitic monomers with diameters of 10-50 nm (Köylü et al., 1995; Bond and Bergstrom, 2006; Bond et al., 2013; Petzold et al., 2013). However, as they evolve in the atmosphere, restructuring of these aggregates occurs due to the above processes and/or condensation of vapours. Compaction can be induced by capillary forces while vapour condensation fills the voids of the aggregates (capillary condensation) (Weingartner et al., 1995; Pagels et al., 2009; Khalizov et al., 2009; Chen et al., 2018, 2016; Ivanova et al., 2021, and references therein) and/or restructuring driven by surface tension forces at the solid-liquid interfaces during condensation of coating material (Kutz and Schmidt-Ott, 1992; Slowik et al., 2007b; Zhang et al., 2008, 2016; Schnitzler et al., 2017). Recently, Ivanova et al. (2021) presented a detailed account of the above processes. As such, increased ageing (temporal and/or chemical) is more likely to result in compact cores (Liu et al., 2019; Laborde et al., 2013); however, the effectiveness of a condensable vapour to cause restructuring also depends on its chemical composition (Xue et al., 2009; Chen et al., 2016). The observed MMD values in this study reflected such transformation processes.

Notably, the NIO-E region depicted a slightly larger mean MMD $(\sim 0.20 \mu \mathrm{m})$ due to frequent larger values $(35 \%$ of the measurements showed MMD $>0.20 \mu \mathrm{m}$ ) compared to all the other regions (Fig. 3d). This is a result of the following possibilities: (i) Self-coagulation of $\mathrm{rBC}$ cores due to enhanced atmospheric ageing during their transport from 

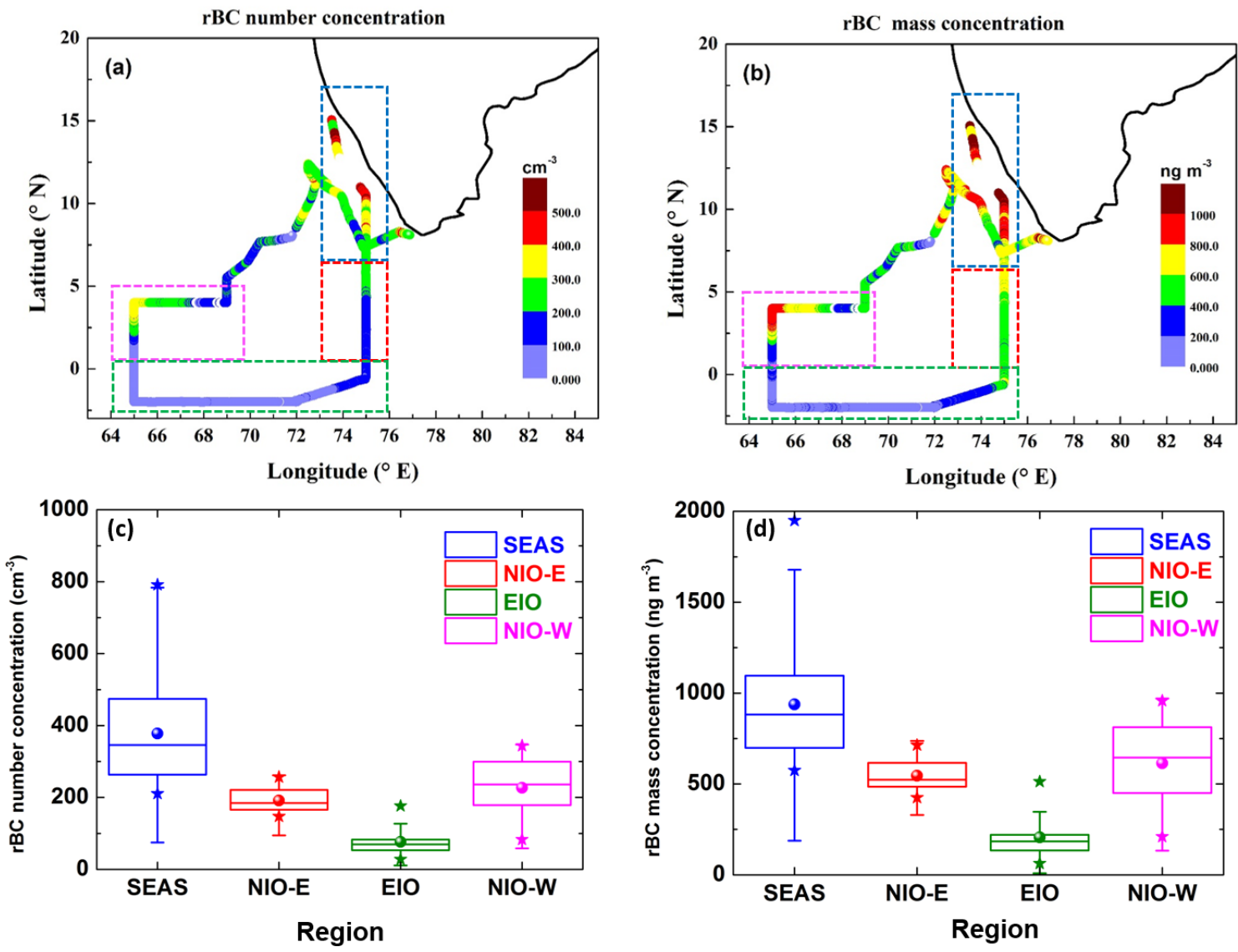

Figure 2. Spatial distribution and box-and-whisker plots of refractory BC (rBC) number $(\mathbf{a}, \mathbf{c})$ and mass concentrations (b, d). The colour scale in the spatial map (a, b) indicates the magnitude of the property. Rectangles with dashed borders highlight different sub-regions. The box-and-whisker plots (c, d) illustrate the mean (sphere), median (the horizontal bar in the box), 25th and 75th percentile (the lower and upper lines of the box), 5th and 95th percentile (end of error bars), and maximum and minimum values for the regions (as solid stars).

the source regions on the east coast to the adjacent marine regions (at the same time, sedimentation of larger particles resulting in a large reduction in number concentration and mass concentration). It may be noted that coagulation, even though it increases the $\mathrm{rBC}$ core diameters and reduces number concentrations, is a slow process. The coagulation rate depends on the square of the particle number concentrations and is the lowest between particles of the same size. Thus, the coagulation rates would be higher near source regions of the nascent aerosols and drop off gradually at farther distances. (ii) The second and most important possibility is associated with the cloud processing of rBC particles. The less-soluble BC particles remain within a non-precipitating cloud as interstitial particles. A cloud undergoes multiple evaporation-condensation cycles before it transforms into a precipitating system. During such cycles, interstitial BC in cloud droplets can grow larger (especially following the evaporation of cloud droplets containing multiple rBC particles) due to agglomeration with other interstitial $\mathrm{rBC}$ aerosols. (iii) The third possibility is the varied nature of dominant sources. A sizable increase in the contribution from solid-fuel sources (biomass/crop residue/coal burning) in the upwind regions (the eastern coast of India) through the transported air masses can lead to larger BC cores (Brooks et al., 2019; Kompalli et al., 2020b). Interestingly, the EIO region showed the largest variability with a non-negligible contribution $(\sim 8 \%)$ from smaller BC cores (MMD $<0.18 \mu \mathrm{m}$ ). Over the NIO-W, the MMD values remained between 0.18$0.20 \mu \mathrm{m}$ suggesting advection of BC originating from mixed sources over peninsular India and/or the west coast. It may be noted that the exact sources cannot be identified from the MMD value of $\mathrm{rBC}$ size distributions alone. More details on source apportionment are provided in Sect. 3.3.

The spatial distribution of NMD also showed a similar picture to that of MMD over all the regions. We compared the MMD values of $\mathrm{rBC}$ observed in our campaign with the values reported from selected locations with distinct dominant sources in different environments in Table 2.

As evident from Table 2, the MMD values during ICARB2018 mostly fall in the category of BC from the continental outflow and originated from mixed sources (McMeeking et al., 2010, 2011; Ueda et al., 2016; Cheng et al., 2018). 
Table 2. A comparison of $\mathrm{rBC}$ average mass median diameters/mode of mass size distributions (MSD) reported from selected locations with distinct sources in different environments.

\begin{tabular}{|c|c|c|c|c|}
\hline S. no. & Location & Type of location/sources & $\begin{array}{l}\text { MSD mode/MMD } \\
(\mu \mathrm{m})\end{array}$ & Reference \\
\hline \multicolumn{5}{|c|}{ Aged air masses in remote/outflow regions } \\
\hline 1. & South-eastern Arabian Sea & Continental outflow/mixed sources & $\begin{array}{l}0.18-0.20 \\
(\text { mean } \sim 0.19 \pm 0.01)\end{array}$ & Present study \\
\hline 2. & Northern Indian Ocean & Continental outflow/mixed sources & $0.19-0.21$ & Present study \\
\hline 3. & Equatorial Indian Ocean & $\begin{array}{l}\text { Outflow impacted remote } \\
\text { marine/mixed sources }\end{array}$ & $\begin{array}{l}0.18-0.21 \\
(\text { mean } \sim 0.19 \pm 0.01)\end{array}$ & Present study \\
\hline 4. & Fukue Island, Japan & Asian outflow & $0.20-0.22$ & Shiraiwa et al. (2008) \\
\hline 5. & Suzu, Japan & Urban/east Asian outflow site & 0.200 & Ueda et al. (2016) \\
\hline 6. & $\begin{array}{l}\text { Mukteshwar, the Himalayas, } \\
\text { India }\end{array}$ & $\begin{array}{l}\text { High-altitude/biofuel, } \\
\text { crop residue outflow }\end{array}$ & $0.21 \pm 0.02$ & Raatikainen et al. (2017) \\
\hline 7. & Jungfraujoch, Switzerland & $\begin{array}{l}\text { High-altitude remote } \\
\text { background/biomass } \\
\text { burning, aged BC }\end{array}$ & $0.22-0.24$ & Liu et al. (2010) \\
\hline 8. & Finnish Arctic & Remote background/aged air mass & $0.15-0.20$ & Raatikainen et al. (2015) \\
\hline 9. & $\begin{array}{l}\text { Alert, Nunavut, Canada } \\
\text { (within the Arctic Circle) }\end{array}$ & Remote background/aged air mass & $0.16-0.18$ & Sharma et al. (2017) \\
\hline 10. & $\begin{array}{l}\text { Catalina Island ( } \sim 70 \mathrm{~km} \\
\text { south-west of Los Angeles) }\end{array}$ & Aged air masses & $0.153-0.170$ & Ko et al. (2020) \\
\hline 11. & Atlantic Ocean & European continental outflow & 0.199 & McMeeking et al. (2010) \\
\hline 12. & Zeppelin, European Arctic & Remote background/aged air mass & 0.24 & Zanatta et al. (2018) \\
\hline \multicolumn{5}{|c|}{ Urban locations } \\
\hline 13. & $\begin{array}{l}\text { Regional average } \\
\text { over Europe }\end{array}$ & $\begin{array}{l}\text { Near source to high altitudes } \\
\text { (a) European continental } \\
\text { (b) Urban outflow }\end{array}$ & $\begin{array}{l}0.17-0.21 \\
\text { (a) } 0.18-0.20 \\
\text { (b) } 0.17 \pm 0.01\end{array}$ & McMeeking et al. (2010) \\
\hline 14. & Bhubaneswar, India & $\begin{array}{l}\text { Urban/fresh urban emissions } \\
\text { Urban/continental outflow, aged BC } \\
\text { Urban/with high solid-fuel emissions }\end{array}$ & $\begin{array}{l}0.17 \pm 0.01 \\
0.18-0.19 \\
0.22 \pm 0.01\end{array}$ & Kompalli et al. (2020b) \\
\hline 15. & $\begin{array}{l}\text { Indo-Gangetic Plain } \\
\text { (aircraft experiment) }\end{array}$ & Urban polluted/mixed sources & $0.18-0.21$ & Brooks et al. (2019) \\
\hline 16. & Gual Pahari, India & $\begin{array}{l}\text { Urban polluted/fresh biofuel, } \\
\text { crop residue }\end{array}$ & $0.22 \pm 0.01$ & Raatikainen et al. (2017) \\
\hline 17. & Shanghai, China & $\begin{array}{l}\text { Urban/pollution episode with } \\
\text { high biomass burning }\end{array}$ & 0.23 & Gong et al. (2016) \\
\hline 18. & London, England & $\begin{array}{l}\text { Urban/traffic emissions } \\
\text { Wood burning }\end{array}$ & $\begin{array}{l}0.119-0.124 \\
0.170\end{array}$ & Liu et al. (2014) \\
\hline 19. & $\begin{array}{l}\text { Canadian oil sand } \\
\text { mining, Canada }\end{array}$ & Urban/fresh urban emissions & $0.135-0.145$ & Cheng et al. (2018) \\
\hline 20. & $\begin{array}{l}\text { Catalina Island }(\sim 70 \mathrm{~km} \\
\text { south-west of Los Angeles) }\end{array}$ & $\begin{array}{l}\text { Biomass burning } \\
\text { Fossil fuel emissions }\end{array}$ & $\begin{array}{l}0.149-0.171 \\
0.112-0.129\end{array}$ & Ko et al. (2020) \\
\hline
\end{tabular}



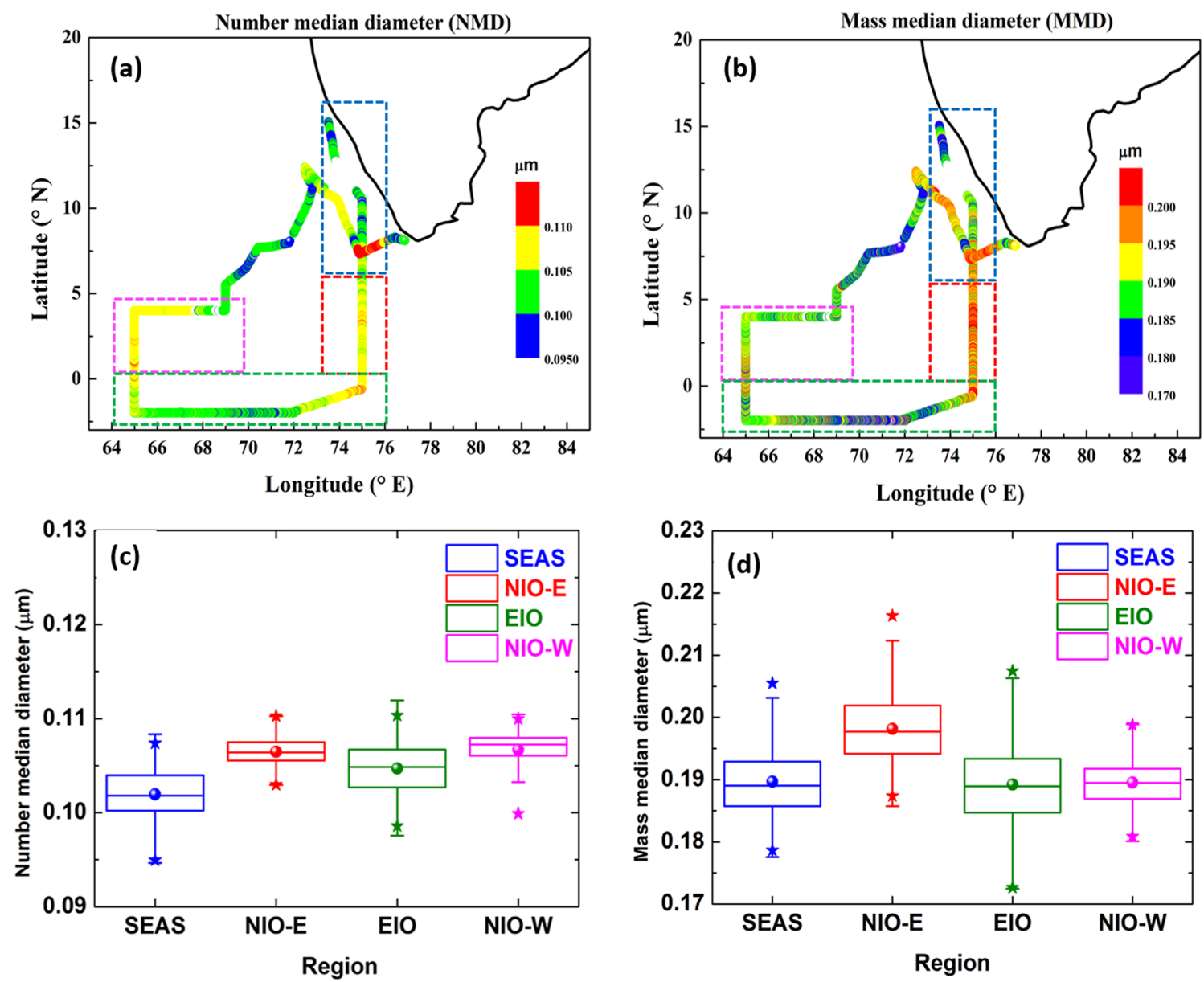

Figure 3. Spatial distribution and the box-and-whisker plots of number median diameter (NMD) (a, c) and mass median diameter (MMD) (b, d) of rBC core size distributions during the ICARB-2018. The colour scale in the spatial map (a, b) indicates the magnitude of the parameter. Rectangles with dashed borders highlight different sub-regions. The box-and-whisker plots (c, d) illustrate the mean (sphere), median (the horizontal bar in the box), 25th and 75th percentile (the lower and upper lines of the box), 5th and 95th percentile (end of error bars), and maximum and minimum values for the regions (as solid stars).

Recently, Kompalli et al. (2020b) also reported mean MMD values of $0.18-0.19 \mu \mathrm{m}$ over Bhubaneswar (located on the east coast of India) during the winter when urban continental outflow with mixed sources from the Indo-Gangetic Plain prevailed. Similarly, Liu et al. (2019) have reported MMD 0.19-0.21 $\mu \mathrm{m}$ in the urban environment of Beijing with mixed sources. The mean MMD values (Table 2) and mass size distributions over different regions covered in this study (Fig. S2 in the Supplement) revealed that although the peak amplitudes varied in proportion to the magnitude of the $\mathrm{BC}$ loading, which decreased with increasing distance from the peninsula, the modal diameters $(0.19-0.20 \mu \mathrm{m})$ showed little variability, which is also underlined by similar geometric standard deviation values $\sim 1.55-1.59$. This is also consistent with the widespread nature of the continental outflow to the northern Indian Ocean (from west to east) and mixed sources for $\mathrm{rBC}$ particles in the outflow (McMeeking et al., 2010).

\subsection{Spatial variation of the $\mathrm{BC}$ aerosol mixing state}

\subsubsection{The bulk coating parameters: RCT and ACT}

The variation of bulk relative coating thickness (RCT) estimated using Eq. (1) and absolute coating thickness (ACT) describes the physicochemical changes in the characteristics of $\mathrm{rBC}$ taking place during atmospheric chemical ageing from the outflow to the oceanic regions. The spatial variation of these parameters during the cruise is shown in the top panels of Fig. 4, while the bottom panels show the frequency of occurrence of these parameters over the different oceanic regions. Corresponding median values are also written in the figures.

The median values show a clear spatial variation of the coating thicknesses (both RCT and ACT), being highest over the SEAS (closest to the coast) and lowest over the EIO (farthest from the landmass). This is attributed to the steadily 

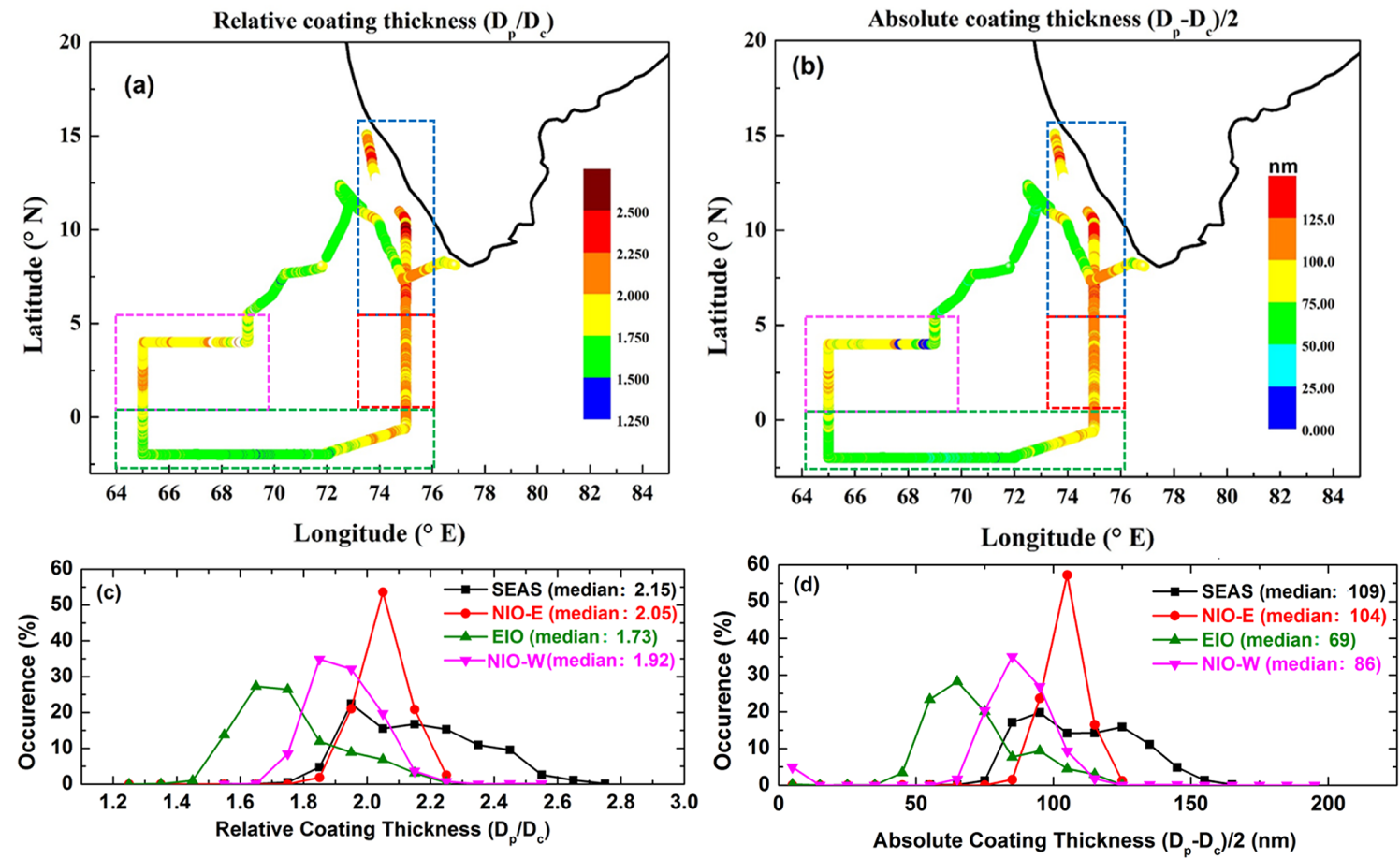

Figure 4. Spatial variation of the bulk (a) relative coating thickness $\left(D_{\mathrm{p}} / D_{\mathrm{c}}\right),(\mathbf{b})$ absolute coating thickness $\left(\left(D_{\mathrm{p}}-D_{\mathrm{c}}\right) / 2\right)($ the colour scale indicates the magnitude), and (c, d) frequency of occurrence of the bulk RCT and ACT in different oceanic sub-regions (shaded following the criteria in Fig. 1). Sub-regional median values are written in the bottom panels.

decreasing concentrations of the coating material in the outflow due to possible dispersion and reactions. The SEAS region, which is in proximity to the coast and immediately impacted by the outflow, displayed a wide range of coating values (Fig. 4c and d), with the highest overall median values $(\mathrm{RCT} \sim 2.15$ and ACT $\sim 109 \mathrm{~nm})$. Notably, two peaks of comparable magnitudes (RCT $\sim 1.95$ and 2.3; ACT $\sim 93$ and $126 \mathrm{~nm}$ ) are visible in the frequency distribution over this region (Fig. 4d), highlighting the large variability due to varied amounts of condensable species and rBC chemical ageing. Nearly $95 \%$ of the observational points over the SEAS region indicated that $\mathrm{rBC}$ particles have an additional coating over their cores to the extent of $>90 \%$ of their size. Such high levels of the coating indicate the availability of high concentrations of condensable materials in the outflow, as have also been reported by other investigators (e.g., Gong et al., 2016; Liu et al., 2019; Brooks et al., 2019). Over the NIO-E region, only thickly coated BC particles are observed where the frequency distributions show a narrow and sharp peak for bulk RCT (median 2.05) and ACT (median $\sim 104 \mathrm{~nm}$ ). This highlighted the contrasting nature of the condensable coating material in the Bay of Bengal and/or the east coast outflow channel compared to the west coast and/or peninsular India outflow channel. Earlier, Moorthy et al. (2005) showed that the east coast and/or coastal Bay of Bengal has stronger hotspots of surface aerosols and gases, as well as a higher abundance of submicron aerosols.
Such variability in the species concentrations in the outflow channels is responsible for the marked contrast in the coating parameters examined here.

As we move farther to the EIO region, RCT and ACT decreased conspicuously, with median values of 1.73 and $69 \mathrm{~nm}$, respectively, with frequency distributions skewed towards lower values. It may be recollected that the lowest BC loading was also noticed over this region (Fig. 2), which experienced air masses that have spent considerable time in the marine atmosphere. The lower coating thickness here is attributed to dilution of the outflow and preferential scavenging processes during the advection restricting the concentrations of both the BC particles and condensable material. With atmospheric and/or chemical ageing, $\mathrm{BC}$ particles become increasingly internally mixed with condensable soluble material, which enhances their removal probability by dry deposition and in-cloud scavenging processes in the atmosphere, including both nucleation scavenging and scavenging by the pre-existing cloud droplets (Miyakawa et al., 2017; Ueda et al., 2018; Zhang et al., 2008). While the larger BC particles are scavenged rather quickly, the smaller and relatively less-coated BC particles (occasionally, even bare soot particles) can persist in the outflow and be transported to the remote marine regions (Ueda et al., 2018). As the particles spend more time in the atmosphere, they tend to gain coating material on them. Simultaneously, the loss of coating material on the particles cannot be ruled out due to photolysis 
or heterogeneous oxidation that can bring about fragmentation, leading to thinner coatings. Thus, preferential scavenging of larger particles leaving behind smaller and more thinly coated particles and atmospheric processes leading to loss of condensable material explains the broad range of MMD (Fig. 3d) and lower RCT values observed over the EIO. Furthermore, in cleaner maritime regions like the equatorial Indian Ocean, the chemical ageing of $\mathrm{BC}$ occurs slowly due to reduced availability of coating material that possibly resulted in the observed smaller coatings on rBC over the EIO region. As the impact of continental outflow increases in the NIO-W, the coating on $\mathrm{rBC}$ increased once again (median RCT $\sim 1.92$ and ACT $\sim 86 \mathrm{~nm}$ ). Interestingly, highly coated BC particles were found less frequently over the NIO-W (with west coast air masses) compared to its eastern counterpart, the NIO-E region, which experienced east coast and/or Bay of Bengal air masses originating from more industrialized upwind locations, e.g., Moorthy et al. (2005), Kompalli et al. (2013). Thus, a clear contrast in the mixing state parameters is evident, which is due to differences in respective coastal sources (Moorthy et al., 2008; Peng et al., 2016; Gong et al., 2016) and possible transit times over these two regions.

It is known that the $\mathrm{BC}$ mixing state depends on various factors, which include the $\mathrm{BC}$ size distribution, nature of sources, the concentration of condensable materials that $\mathrm{BC}$ encounters during its atmospheric lifetime, and processes such as photochemical ageing (Liu et al., 2013; Ueda et al., 2016; Miyakawa et al., 2017; Wang et al., 2018, 2019). The values of BC coating parameters (bulk RCT and ACT) seen in the present study that examined outflow characteristics are comparable to the values reported in pollution in-plume air mass regions elsewhere (e.g., Cheng et al., 2018; Brooks et al., 2019). Recently, Kompalli et al. (2020b) reported seasonal mean bulk relative coating thickness (RCT) in the range of $\sim 1.3-1.8$ and ACT $\sim 50-70 \mathrm{~nm}$ over Bhubaneswar when the site received polluted outflow from the Indo-Gangetic Plain (IGP). Brooks et al. (2019) noticed thickly coated BC particles (ACT 50-200 nm) across northern India, especially the IGP and north-east India, during their recent aircraft experiments. As Cheng et al. (2018) and Ko et al. (2020) have highlighted, coating parameters derived from the SP2 instruments having different system configurations (detection limits of scattering intensity and range of volume equivalent diameters covered) and different techniques used in the estimation of the optical diameters from scattering amplitudes (Metcalf et al., 2012; Gong et al., 2016; Raatikainen et al., 2017; Cheng et al., 2018; Liu et al., 2019; Ko et al., 2020) can vary considerably. This caveat needs to be borne in mind when making inter-study comparisons. Also, the earlier studies are mostly made in the "near-field" situation, whereas the present study examined the coating characteristics in a "far-field" scenario (far away from potential sources, especially the NIO and EIO regions). The caveat here is that the present study is not a Lagrangian experiment, and it is possible that the far-field measurements are influenced by mixing with the surrounding environment. Nevertheless, such a high degree of coatings on BC considerably enhances its absorption cross section, which thereby causes substantial absorption enhancement (by the factors in the range of 1.6-3.4) and affects the radiative forcing (Moffet and Prather, 2009; Shiraiwa et al., 2010; Thamban et al., 2017; Liu et al., 2015; Wang et al., 2018). The implication of the observed thick coatings on $\mathrm{BC}$ to regional radiative forcing needs further detailed investigation in future studies.

\subsubsection{Coated $\mathrm{BC}$ diameter, $F_{\mathrm{BC}}$, and bulk mixing ratio ( $\left.M_{\mathbf{R}, \text { bulk }}\right)$}

The spatial variation of number concentration $\left(\right.$ in $\mathrm{cm}^{-3}$ ) of non-BC (i.e., purely scattering) particles detected by the SP2 and the fraction of $\mathrm{rBC}$-containing particles $\left(F_{\mathrm{BC}}\right.$; the ratio of $\mathrm{rBC}$ number concentration to the total number concentration in size range of $10-1000 \mathrm{~nm}$ from the SMPS and APS measurements) are shown in Fig. 5a and b. The bottom panels of the same figure show the volume-weighted coated BC size $\left(D_{\mathrm{p}, \mathrm{v}}\right)($ in $\mu \mathrm{m})($ Fig. $5 \mathrm{c})$ and bulk mixing ratio of coating mass to $\mathrm{rBC}$ mass $\left(M_{\mathrm{R}, \text { bulk }}\right)$ (Fig. $\left.5 \mathrm{~d}\right)$ calculated using the Eqs. (3) and (4).

The overall spatial variation patterns of scattering particle concentrations and various mixing state parameters are similar to those of the $\mathrm{rBC}$ mass and number concentrations seen earlier, with the highest values over the SEAS, decreasing gradually towards the NIO (east and west) to reach the lowest values over the remote EIO. The figure reveals the following:

i. The non-BC (scattering) particle concentrations were higher, $>1000 \mathrm{~cm}^{-3}$, in the coastal waters (the SEAS), decreasing towards farther oceanic regions and reached values as low as $<200 \mathrm{~cm}^{-3}$ in the remote EIO, which is in line with the expected reduction in the influence of the sources (Fig. 5a).

ii. The rBC particles constituted about $8 \%-12 \%$ of the total particle number concentration over different subregions, on average (Fig. 5b). The $F_{\mathrm{BC}}$ values showed the largest variability over the SEAS among all the regions (Fig. 5b).

iii. Coated rBC particles were larger $\left(D_{\mathrm{p}, \mathrm{v}} \sim 0.35-\right.$ $0.50 \mu \mathrm{m}$ ) over coastal waters (SEAS), highlighting a substantial enhancement of the overall $\mathrm{rBC}$ particle sizes due to thick coatings on them in the polluted outflow air masses. The values diminished farther away, and the lowest values $(<0.30 \mu \mathrm{m})$ are seen over the EIO region (Fig. 5c).

iv. The bulk mixing ratio of coating mass over $\mathrm{rBC}$ mass $\left(M_{\mathrm{R}, \text { bulk }}\right)$ revealed high values (2.5-15) with large variability over the regions with extensive outflow (SEAS) due to the presence of thickly coated BC particles in these regions. Though $M_{\mathrm{R} \text {,bulk values were very low }}$ 

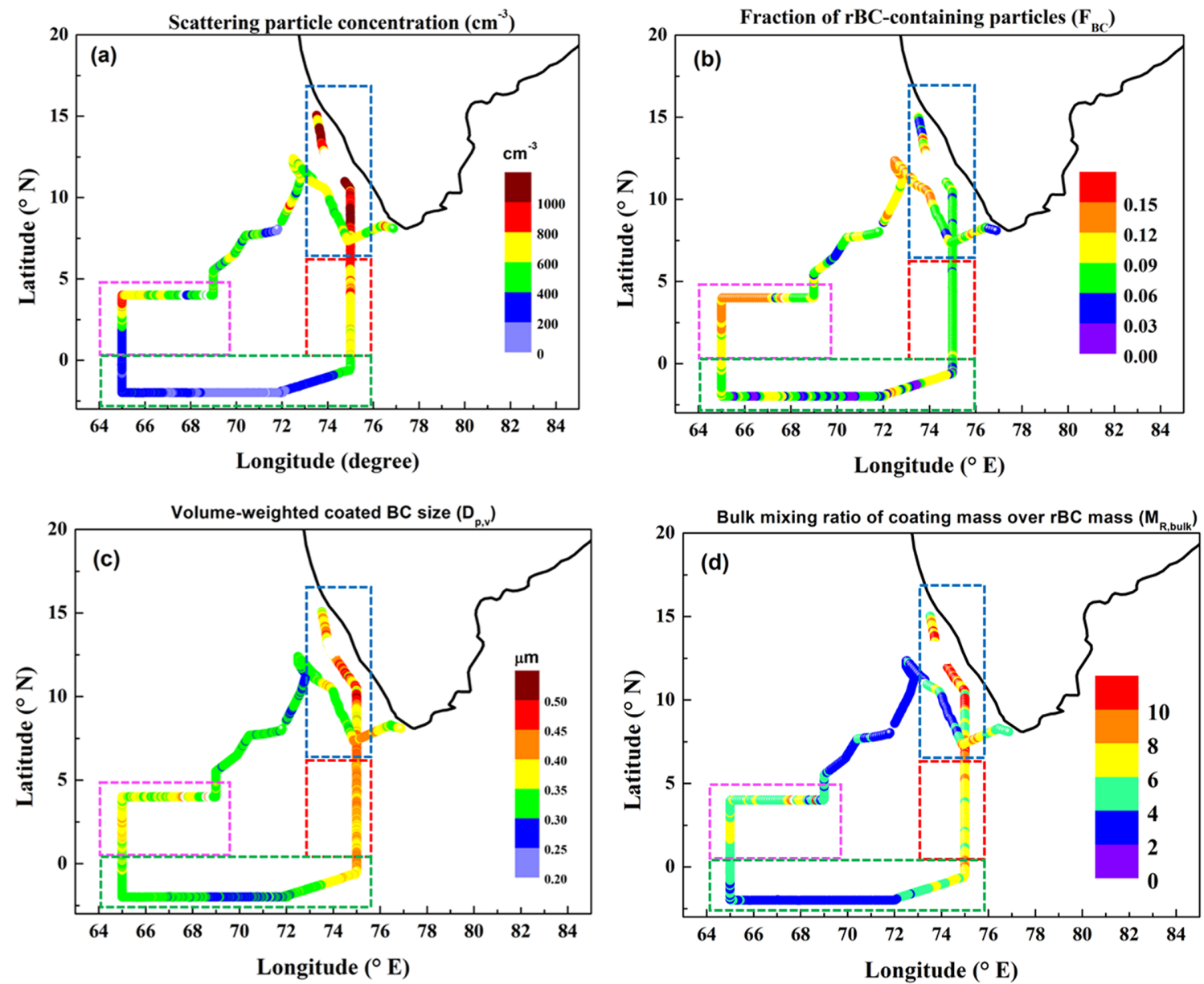

Figure 5. Spatial variation of the (a) scattering (non-BC) particle number concentration (in $\mathrm{cm}^{-3}$ ), (b) fraction of rBC-containing particles $\left(F_{\mathrm{BC}}\right)$, (c) volume-weighted coated BC size $\left(D_{\mathrm{p}, \mathrm{v}}\right)($ in $\mu \mathrm{m})$, and (d) bulk mixing ratio of coating mass to rBC mass $\left(M_{\mathrm{R}, \text { bulk }}\right)$. Rectangles with dashed borders highlight different sub-regions.

over the EIO, occasional higher values $(>4)$ are also seen (Fig. 5d).

Interestingly, concentrations of scattering (non-BC) particles (Fig. 5a) over the SEAS (mean $\sim 973 \pm 187 \mathrm{~cm}^{-3}$ ) and the NIO-E (mean $\sim 747 \pm 69 \mathrm{~cm}^{-3}$ ) are comparable to or higher than the values reported over the IGP outflow site, Bhubaneswar (winter mean $\sim 950 \pm 464 \mathrm{~cm}^{-3}$; annual mean $\sim 702 \pm 458 \mathrm{~cm}^{-3}$ ), as reported by Kompalli et al. (2020b). This highlighted the strength of the outflow to the oceanic regions. Any increase in non-BC particle abundance impacts the fraction of $\mathrm{rBC}$-containing particles. The mean fraction of $\mathrm{rBC}$-containing particles $\left(F_{\mathrm{BC}}\right)$ that were in the range of $0.08-0.12$ over different sub-regions occasionally decreased to very low values of $\sim 0.02$ to 0.04 , owing to a large influx of ultrafine particles (sizes $<100 \mathrm{~nm}$ ) during the new particle formation events that occurred due to substantial amounts of condensable vapours (Kompalli et al., 2020a). The highest fraction of $\mathrm{rBC}$-containing particles was seen over the NIO-W $(0.12 \pm 0.03)$ region, whereas the largest range of
$F_{\mathrm{BC}}$ values (0.03-0.21) among all the regions were observed over the SEAS. The present mean $F_{\mathrm{BC}}$ values seen over the northern and equatorial Indian Ocean are lower than those reported over the Finnish Arctic $(\sim 0.24$ across the 350 to $450 \mathrm{~nm}$ size range), a background site receiving aged air masses (Raatikainen et al., 2015). However, earlier studies over the continental landmass of India have shown much higher number fractions with mean $F_{\mathrm{BC}}$ values $\sim 0.51 \pm 0.02$ and $0.50 \pm 0.03$ over two stations, Gual Pahari (polluted site) and Mukteshwar (regional background site), in northern India (Raatikainen et al., 2017). This was attributed to the strong influence of regional anthropogenic activities on $\mathrm{BC}$ loading. In the present study, rBC particles constituted about $25 \%$ to $30 \%$ of the measured scattering particles over almost the entire oceanic region north of $5^{\circ} \mathrm{N}$, whereas they occasionally decreased to $15 \%$ to $20 \%$ over the far oceanic regions. Kompalli et al. (2020b) reported widely varied mean fractions ( $25 \%-69 \%$ of the measured scattering particles in different seasons) over Bhubaneswar (eastern India) with the same instrument. They attributed it to the seasonal variation 
of the scattering (non-BC) particle population. Sharma et al. (2017) have reported $10 \%-16 \%$ of particles containing rBC cores in the range of $\sim 200-400 \mathrm{~nm}$ optical diameter over Alert in the Canadian Arctic. The presence of lower $F_{\mathrm{BC}}$ values over the marine regions in this study, which received a strong continental outflow, is not surprising, considering the observed large number concentration of total particles (Kompalli et al., 2020a) and the non-BC scattering particles in the detection range of the SP2 $(200-400 \mathrm{~nm})$ (along with $\mathrm{rBC}$ particles).

Strong continental outflows (from the polluted regions) are more likely to contain significant amounts of condensable material that can act as a potential coating on $\mathrm{rBC}$ (Liu et al., 2014, 2019; Raatikainen et al., 2017). This is reflected in the observed high values of coated BC particle diameters $(0.36-0.55 \mu \mathrm{m})$ in this study (Fig. $5 \mathrm{c}$ ). The present $D_{\mathrm{p}, \mathrm{v}}$ values over the northern Indian Ocean region are higher than those recently reported by Brooks et al. (2019) $(\sim 0.25-$ $0.30 \mu \mathrm{m}$ ) over the IGP and eastern India, but comparable to the values reported by Raatikainen et al. (2017) for thickly coated BC particles in polluted outflow environments in northern India.

The higher bulk mixing ratio of coating mass over rBC mass values $\left(M_{\mathrm{R} \text {,bulk }} \sim 2.5-15\right)$ (Fig. $\left.5 \mathrm{~d}\right)$ is seen over the adjacent marine regions and due to the presence of thickly coated BC particles. Though lower compared to other subregions, substantial $M_{\mathrm{R} \text {,bulk }}(\sim 4.24 \pm 1.45)$ values were found even over the EIO region. Such high $M_{\mathrm{R} \text {,bulk values }}$ were reported in the literature from extremely polluted environments and biomass burning source dominant regions (Liu et al., 2017, 2019). The presence of such non-absorbing coated mass on the rBC cores has significant radiative implications. Recently, Liu et al. (2017) examined the measured and modelled optical properties of $\mathrm{BC}$ as a function of mass ratio $\left(M_{\mathrm{R}, \text { bulk }}\right)$ under different environments and found that significant absorption enhancement occurs when the coating mass over $\mathrm{rBC}$ mass is larger than 3 . They suggested that in such a scenario (i.e., $M_{\mathrm{R}, \text { bulk }}>3$ ), the core-shell model reproduces the measured scattering cross section.

A summary of $\mathrm{rBC}$ physical properties and mixing state parameters in different oceanic regions are presented in Table 3 .

Table 3 highlights the spatial heterogeneity in $\mathrm{rBC}$ microphysical properties over the northern Indian ocean. It reveals the contrast in outflow strength with varied extents of $\mathrm{BC}$ and non-BC species abundance on the west coast/peninsular India and the east coast and/or Bay of Bengal air masses. Table 3 also highlights the diminishing strength of the outflow as seen from the lower concentrations, coatings, and associated mixing state parameters over the EIO region.

\subsection{BC segregation by size-resolved mixing state}

The above discussions have established that i. The extent of the coating as measured by the coating thickness and the bulk mixing ratio of coating mass over $\mathrm{rBC}$ mass, and hence the mixing of $\mathrm{BC}$ with condensable species, is highest closer to the coast where the outflow is strong and decreases in the farther oceanic regions.

ii. The $\mathrm{rBC}$ core diameters, as well as the fractional concentration of $\mathrm{rBC}$ to total concentration, remained more or less comparable throughout the oceanic regions surveyed, suggesting an impact of similar sources of mixed origin. However, the coated BC diameters varied according to the magnitude of coating over different regions.

To examine these common sources, the size-resolved BC mixing state is examined from the variation in scattering enhancement ( $E_{\text {sca }}$, Eq. 5$)$ as a function of BC core diameter $\left(D_{\mathrm{c}}\right)$ in Fig. 6 . The corresponding bulk absolute coating thickness (ACT) values are mapped to the $E_{\text {sca }}$ (solid white lines) in the figure. The data collected from 16:41:24 on 21 January 2018 to 18:02:46 on 22 January 2018 (Indian standard time) were used to construct the figure (which falls in the transition period between the SEAS and NIOE regions). The same analysis repeated for a few other data sets over the other regions also yielded similar results. Following the methodology described in previous publications (Liu et al., 2014, 2019; Brooks et al., 2019), the BC particles are segregated according to the discontinuous distribution in $E_{\text {sca }}-D_{\mathrm{c}}$ (dashed black lines in the figure). Four classes of $\mathrm{BC}$ particles are described: (a) small $\mathrm{BC}$ with a thin coating, i.e., with $\mathrm{BC}$ core diameters $<0.18 \mu \mathrm{m}$ and $\mathrm{ACT}<50 \mathrm{~nm}$; (b) moderately coated $\mathrm{BC}$, with $\mathrm{ACT}$ in the range of 50 $200 \mathrm{~nm}$; (c) thickly coated BC with ACT > $200 \mathrm{~nm}$; and (d) large uncoated $\mathrm{BC}$, with $\mathrm{BC}$ core size $>0.18 \mu \mathrm{m}$ and coating thicknesses $<50 \mathrm{~nm}$. In the present study, there is no noteworthy presence of a clear smaller sized BC with a thin coating, which is generally attributed to fresh traffic emissions (e.g., Liu et al., 2014, over London; Liu et al., 2019, over Beijing). Brooks et al. (2019) also found smaller contributions from such particles during aircraft observations over the north-west and north-east parts of India carried out in the dry season.

The main features in the figure are

a. A reasonable amount of moderately coated $\mathrm{BC}$ particles having ACT of $\sim 50-100 \mathrm{~nm}$ with scattering enhancements in the range of $E_{\mathrm{sca}} \sim 2-10$ were seen, and a significant proportion of moderately coated $\mathrm{BC}$ particles with large scattering enhancement $\left(E_{\text {sca }} \sim 10\right.$ 100 ), which increased with $\mathrm{BC}$ core sizes during the ICARB cruise. This highlighted the substantial contribution from a combination of mixed sources that coemit BC and condensable material (Liu et al., 2014, 2019). 
Table 3. A summary of regional mean values of rBC physical properties and mixing state parameters during the ICARB-2018. The values after \pm are standard deviations.

\begin{tabular}{lrrrr}
\hline Parameter & SEAS & NIO-E & EIO & NIO-W \\
\hline rBC mass concentration $\left(\mathrm{ng} \mathrm{m}^{-3}\right)$ & $938 \pm 293$ & $546 \pm 80$ & $206 \pm 114$ & $614 \pm 211$ \\
rBC number concentration $\left(\mathrm{cm}^{-3}\right)$ & $378 \pm 137$ & $191 \pm 32$ & $76 \pm 38$ & $227 \pm 76$ \\
Scattering particle concentration $\left(\mathrm{cm}^{-3}\right)$ & $973 \pm 187$ & $747 \pm 69$ & $262 \pm 140$ & $580 \pm 156$ \\
Mass median diameter $(\mu \mathrm{m})$ & $0.19 \pm 0.01$ & $0.20 \pm 0.01$ & $0.19 \pm 0.01$ & $0.19 \pm 0.004$ \\
Number median diameter $(\mu \mathrm{m})$ & $0.10 \pm 0.002$ & $0.11 \pm 0.003$ & $0.11 \pm 0.003$ & $0.107 \pm 0.002$ \\
Relative coating thickness & $2.16 \pm 0.19$ & $2.05 \pm 0.07$ & $1.76 \pm 0.16$ & $1.93 \pm 0.10$ \\
Absolute coating thickness $(\mathrm{nm})$ & $109 \pm 20$ & $104 \pm 7$ & $72 \pm 17$ & $85 \pm 21$ \\
Fraction of rBC-containing particles $\left(F_{\mathrm{BC}}\right)$ & $0.08 \pm 0.03$ & $0.08 \pm 0.01$ & $0.08 \pm 0.03$ & $0.12 \pm 0.03$ \\
Volume-weighted coated BC size $\left(D_{\mathrm{p}, \mathrm{v}}\right)(\mu \mathrm{m})$ & $0.41 \pm 0.04$ & $0.41 \pm 0.01$ & $0.33 \pm 0.04$ & $0.37 \pm 0.02$ \\
Bulk mixing ratio of coating mass over $\mathrm{rBC}$ mass $\left(M_{\mathrm{R}, \text { bulk }}\right)$ & $8.31 \pm 2.40$ & $6.91 \pm 0.71$ & $4.24 \pm 1.45$ & $5.76 \pm 1.17$ \\
\hline
\end{tabular}

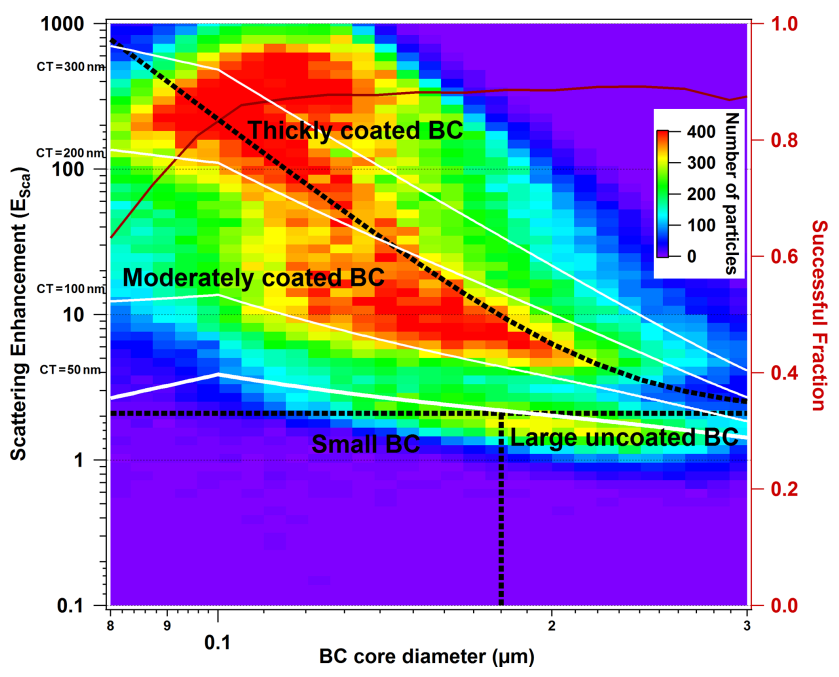

Figure 6. Scattering enhancement $\left(E_{\mathrm{sca}}\right)$ as a function of $\mathrm{BC}$ core size $\left(D_{\mathrm{c}}\right)$ for the typical outflow air masses during the ICARB-2018. The plot is coloured by particle number concentration. The solid brown line, with the corresponding scale on the right axis, shows the number fraction of $\mathrm{BC}$ particles that were successfully determined according to their scattering signal at each $D_{\mathrm{c}}$ size. The image plot is a two-dimensional histogram for the detected particles. The particles are separated as four groups using the borders (from top to bottom) at $y=3.38+0.000436 \cdot x^{-5.7}, y=2.1$, and $x=0.18$, as shown by dashed black lines on the figure (Liu et al., 2019). The solid white lines show the absolute coating thickness (ACT, nm) mapped on the $E_{\mathrm{sca}}-D_{\mathrm{c}}$ plot.

b. Even smaller-sized BC cores (which possibly originate from fossil fuel emissions and transform to larger cores during the atmospheric transit) were significantly coated with resultant scattering enhancement $>100$ during the ICARB-2018, which highlights the extent of chemical ageing of $\mathrm{BC}$ particles in the continental outflow. Such faster chemical ageing of smaller cores is possible in the polluted air masses (Gong et al., 2016). Similarly, faster chemical ageing of large BC particles that generally originate from biomass burning sources results in moderate to thicker coating (Schwarz et al., 2008; Gong et al., 2016) and amplified scattering enhancement (Liu et al., 2019), which is also seen from Fig. 6.

c. Remarkably, a greater proportion of thickly coated particles with varied $\mathrm{BC}$ core diameters and a wide range (5-800) of scattering enhancement values were also observed, further highlighting a strong mixed source influence of the continental outflow.

Besides the normal mode similar to the one (with core diameter $<0.22 \mu \mathrm{m}$ and coating thickness of $50-200 \mathrm{~nm}$ ) reported from the aircraft measurements of $\mathrm{BC}$ mixing state over the Indian continent by Brooks et al. (2019), an additional mode of $\mathrm{BC}$ with $\mathrm{BC}$ core sizes $\sim 110-130 \mathrm{~nm}$ and a significant coating thickness $(>200 \mathrm{~nm}$ ) is seen during this study. Such a mode highlights the influence of longrange transport to the ocean from the continent on $\mathrm{BC}$ chemical ageing. Though the $\mathrm{BC}$ mass loading decreases during the long-range transport, the remaining $\mathrm{BC}$ cores gain a greater coating over the ocean than over land (e.g., Moteki et al., 2007). Further, it indicates a strong secondary production of aerosol components during the transport over the ocean, contributing to the $\mathrm{BC}$ chemical ageing. The much thicker coatings seen during the ICARB-2018 compared to the observations from the ground-based site (Kompalli et al., 2020b) and the aircraft measurements (Brooks et al., 2019) over the Indian region are also indicative of other sources (with poor combustion efficiencies such as biomass burning) being prevalent in this region. Gong et al. (2016) have reported thick ACT $(\sim 110-300 \mathrm{~nm})$ values during a biomass burning pollution episode in urban Shanghai, comparable to the present BC mode. These values are higher than the values reported from the aircraft measurements over biomass burning plumes ( $150 \mathrm{~nm}$; Ditas et al., 2018), the south-east Atlantic Ocean $(\sim 90 \mathrm{~nm}$ in the boundary layer and $\sim 120 \mathrm{~nm}$ in the free troposphere; Taylor et al., 2020), and aged smoke in Amazonia (55-90 nm) (Darbyshire et 
al., 2019). Therefore, the measurement over the ocean thus offers an opportunity to study a more chemically aged BC from the continent outflow.

The high proportion of thick coatings on $\mathrm{BC}$ particles may result in significant increases in absorption by the BC. As reported by Brooks et al. (2019) from measurements over the IGP, a significant fraction of moderately coated BC particles with increased scattering enhancement were found to have higher mass absorption coefficient values over the IndoGangetic Plain. They attributed this to vigorous mixing between various sources due to the high amounts of secondary aerosol formation and photochemical ageing across northern India. The present scenario, with a steady pollutant outflow containing contributions from diverse sources, is akin to it. Such alterations to the mixing state of $\mathrm{BC}$ can contribute to significant enhancement in the absorbing characteristics of $\mathrm{BC}$ aerosols over the marine regions as they underdo chemical ageing while transiting from upwind source regions on the west and east coasts of India, which may have noteworthy regional climate implications.

The large uncoated $\mathrm{rBC}$ particles (core diameters $>$ $0.18 \mu \mathrm{m}$ and thin coatings of ACT $<50 \mathrm{~nm}$ ) with low scattering enhancements were also found during our measurements but in smaller quantities, consistent with the findings of Brooks et al. (2019) for the Indian region during the pre-monsoon and monsoon seasons. Liu et al. (2019) described that large uncoated $\mathrm{rBC}$ particles are indicative of coal-burning emissions and suggested that larger core $\mathrm{BC}$ particles with no or thin coatings display minimal $E_{\text {sca }}$ values. This can be due to significant bias introduced by the sphericity assumption used in the Mie calculations and a possible difference in the refractive index of $\mathrm{BC}$ produced from coal-burning from the value assumed $(\sim 2.26 \pm 1.26 i)$ in the Mie calculations used to derive $E_{\text {sca }}$. However, this aspect cannot be addressed in the present study in the absence of measurements of BC morphology or source-dependent refractive index of rBC. As such, a more detailed in situ analysis is necessary to address this.

\subsection{Association between $\mathrm{BC}$ coating thickness and NR-PM 1.0 chemical species}

Information on the nature of the coating material along with the state of mixing of $\mathrm{BC}$ particles gives insight into the magnitude of the mixing-induced absorption enhancement for BC (Cappa et al., 2012, 2018; Peng et al., 2016; Liu et al., 2017). We have used the concurrent measurements of non-refractory $\mathrm{PM}_{1.0}\left(\mathrm{NR}-\mathrm{PM}_{1.0}\right)$ aerosol mass and chemical composition data from the ACSM to infer the nature of the coating material during the ICARB-2018. Though it may be possible for $\mathrm{BC}$ to be mixed externally with coarse mode aerosols like dust or sea-salt aerosols in the real atmosphere, Fig. 6 directly dispels the importance of this notion.

General features of NR-PM 1.0 chemical composition are shown in Fig. 7, which shows the sub-regional mean mass
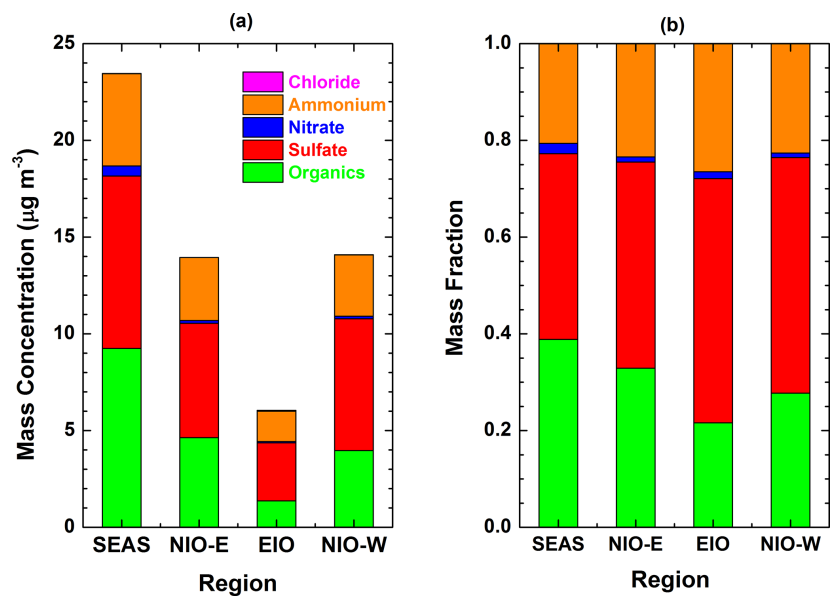

Figure 7. (a) Mass concentration and (b) mass fraction of NR$\mathrm{PM}_{1.0}$ chemical species, organics, sulfate, ammonium, nitrate, and chloride over different sub-regions during the ICARB-2018.

concentrations and mass fractions (MF) of different species over the oceanic regions covered during the cruise.

In line with the pattern for $\mathrm{rBC}$, the overall NR-PM $\mathrm{PM}_{1.0}$ aerosol mass concentration was also highest over the SEAS (mean $\sim 23.44 \pm 5.07 \mu \mathrm{g} \mathrm{m}^{-3}$ ), decreasing steadily further away from the continent to reach the lowest concentrations $\left(\sim 5.48 \pm 2.83 \mu \mathrm{g} \mathrm{m}^{-3}\right)$ over the EIO, where mostly oceanic air masses prevailed. Sulfate and organics were the two major species dominating the NR-PM 1.0 composition. Of these two, sulfate dominated most of the oceanic sub-regions with a mass fraction $\geq 0.4$ except for the SEAS region, where organics $(\sim 0.39)$ were also equally important. The mass fraction of ammonium, which is formed through gas-phase and aqueous-phase chemical reactions of $\mathrm{NH}_{3}$ produced from animal wastes, fertilizers, ocean, and soil, was in the range of $\sim 0.20-0.23$, while nitrate (0.01-0.02) and chloride are negligible in all the regions. To summarize, the South Asian outflow plumes consist of more or less equal proportions of organics and sulfate aerosols in the vicinity of the west coast and/or peninsular India, gradually changing to a sulfate-rich aerosol system in the remote oceanic regions. This marked change from the prominent presence of organics plus sulfate over coastal regions to a strong sulfate dominance over the remote oceanic regions emphasized the atmospheric processes (formation, transformation, and removal) that are at play in determining the life cycle of these species during their transport. Possible oxidation of primary particulate organic matter due to heterogeneous reactions involving oxidants such as $\mathrm{OH}, \mathrm{O}_{3}$, and $\mathrm{NO}_{3}$ during long-range transport can result in their volatilization, thus restricting their lifetime (Molina et al., 2004; Donahue et al., 2006; DeCarlo et al., 2010). However, enhanced sulfate production is possible through the gas to particle conversion in the $\mathrm{SO}_{2}$-rich air masses (especially when ambient relative humidity is higher) (Unger et al., 2006; Meng et al., 2016) that originate over the 
Indian region or through the dimethyl sulfide (DMS) pathway from the marine emissions (Zorn et al., 2008; Shank et al., 2012). During long-range transport, in situ oxidation of $\mathrm{SO}_{2}$ by $\mathrm{OH}$ radicals in the gas phase followed by condensation onto pre-existing particles or reaction of $\mathrm{S}(\mathrm{IV})$ via $\mathrm{H}_{2} \mathrm{O}_{2}$ and $\mathrm{O}_{3}$ in the aqueous phase can lead to enhanced sulfate concentrations. All such processes could have contributed to observed spatial heterogeneity in the observed organics to sulfate concentrations. Detailed investigation of these processes is not within the scope of the present study.

Further, the association between ammonium and sulfate (Fig. S3 in the Supplement) indicated an $\mathrm{NH}_{4}^{+}$deficit environment (Aswini et al., 2020). In Fig. S4 in the Supplement, the ratio (expressed as \%) of non-refractory coating mass on $\mathrm{BC}$ to the total NR-PM 1.0 mass concentrations (from the ACSM) are shown. The mean ratios (varying between $23 \%-$ $35 \%$ ) for different sub-regions are also mentioned in the figure.

We examined the association between bulk absolute coating thickness (inferences did not change even if we use RCT) and mass concentrations of NR-PM $\mathrm{P}_{1.0}$ organic aerosols, sulfate, and ammonium during the campaign (Fig. 8) when ACT is low (ACT $<50 \%$ of MMD) (Fig. 8a-c) and high (ACT $>50 \%$ of MMD) (Fig. 8d-f). The colour bar indicates the values of the corresponding MMDs. The solid line is the linear least squares fit between the variables and the corresponding correlation coefficient (Pearson's $r$ ) is also shown in the figure.

Regression analysis suggested two distinct regression lines in the sulfate and ammonium plots. The bulk ACT showed a reasonable association $(r>0.6 ; p<0.01)$ with $\mathrm{NR}_{-} \mathrm{PM}_{1.0}$ sulfate and ammonium and a weaker association with organics $(r \sim 0.41 ; p<0.01)$ during low (ACT $<50 \%$ of MMD) observations. Corresponding slopes indicated that ACT on BC intensified more steeply with an enhanced mass concentration of sulfate (slope $\sim 2.14$ ) compared to organics (slope $\sim 1.18$ ), whereas the steepest enhancement in the ACT was noticed for ammonium (slope $\sim 7.15$ ). In contrast, there is no significant association between bulk ACT and mass concentrations of NR-PM 1.0 species during high ACT (ACT $>50 \%$ of MMD) observations. In this case, higher ACT values prevailed for all values of sulfate (or organics) and ammonium. The low and high ACT groups of observations are distinctly separated by the corresponding MMD values, where more frequent higher MMD values were seen for the $\mathrm{BC}$ population having a higher coating.

Thus, Fig. 8 suggested the possibility of complex coating on $\mathrm{BC}$ in the proximity of continental outflow where higher ACT (also higher MMD), significant amounts of organics, and ammonium were observed. In the far oceanic regions, sulfate components can act as a relatively dominant coating material on BC (compared to organics). This is not unexpected considering the chemically aged $\mathrm{BC}$ particles that were present in the remote marine boundary layer dominated by the sulfate aerosol system. Previously, Ueda et al.
(2018) reported morphological features of soot-containing particles over the Southern Ocean and suggested that aged soot-containing particles were transformed by soluble materials derived from dimethyl sulfide (DMS) oxidation during the summer. Though this DMS oxidation pathway may not be strong for in situ production during the winter, it may be important when the reactions during entrainment of free tropospheric air masses into remote marine atmospheric boundary layer are considered (e.g., Clarke and Kapustin, 2002). Zhang et al. (2008) suggested that soot particles acquire a large mass fraction of sulfuric acid during atmospheric ageing. It is well known that semivolatile organic compounds are lost during atmospheric ageing due to evaporation following the dilution and oxidation of primary organics due to heterogeneous reactions (Donahue et al., 2006; Lambe et al., 2013). Such chemical ageing (the degree of oxygenation) of organics has previously been identified by increasing $f_{44}$ and decreasing $f_{43}$, which are the ratios between the massto-charge ratios at 44 and 43 and the total organics signal in the component mass spectrum, respectively (Ng et al., 2011). During this cruise, gradual increases in $f_{44}$ and decreases in $f_{43}$ were observed with distance from the coast. However, as described earlier, sulfate concentrations can increase due to the heterogeneous in situ oxidation of $\mathrm{SO}_{2}$ and condensation of sulfuric acid onto pre-existing particles after gasphase oxidation of $\mathrm{SO}_{2}$ during long-range transport (Kompalli et al., 2020b, and references therein). These processes can contribute to the alteration of the mixing state of $\mathrm{BC}$, which is a relatively longer-lived species, and determine its dominant coating material. Another interesting possibility is organosulfates acting as a coating material on BC, but examining it is beyond the scope of the present study.

The MMD values of $\mathrm{rBC}$ showed no particular pattern with changing NR-PM $\mathrm{P}_{1.0}$ species mass concentrations. Further, the rBC mass concentrations showed a good association with organics $(r \sim 0.78)$ and sulfate $(r \sim 0.71)$ (not shown), corroborating the presence of multiple sources that co-emit particulate organics and sulfate along with $\mathrm{BC}$ aerosols. As described earlier, the mean fraction of rBC-containing particles remained similar $(\sim 8 \%)$ over different regions (SEAS, NIO-E, and EIO). However, frequent new particle formation events (Kompalli et al., 2020a) resulted in lower $F_{\mathrm{BC}}$ $(<2 \%)$, which is reflected in the amounts of NR-PM 1.0 mass that are bound to $\mathrm{rBC}$ particles. It was observed that new particle formation and subsequent growth to larger sizes preceded an enhancement in the mass concentrations of submicron aerosols (mostly organics and occasionally sulfate). This suggests another possibility of a reduction in the primary particulate pollution, and the available secondary condensate promotes nucleation in such cases. Also, the portion of the non-refractory submicron aerosol mass bound to the BC particles varied over a wide range of $10 \%-40 \%$ over different regions (Fig. S4 in the Supplement) and lower values were especially seen during new particle formation (NPF) periods (not shown here). Figure S5 in the Supplement shows 

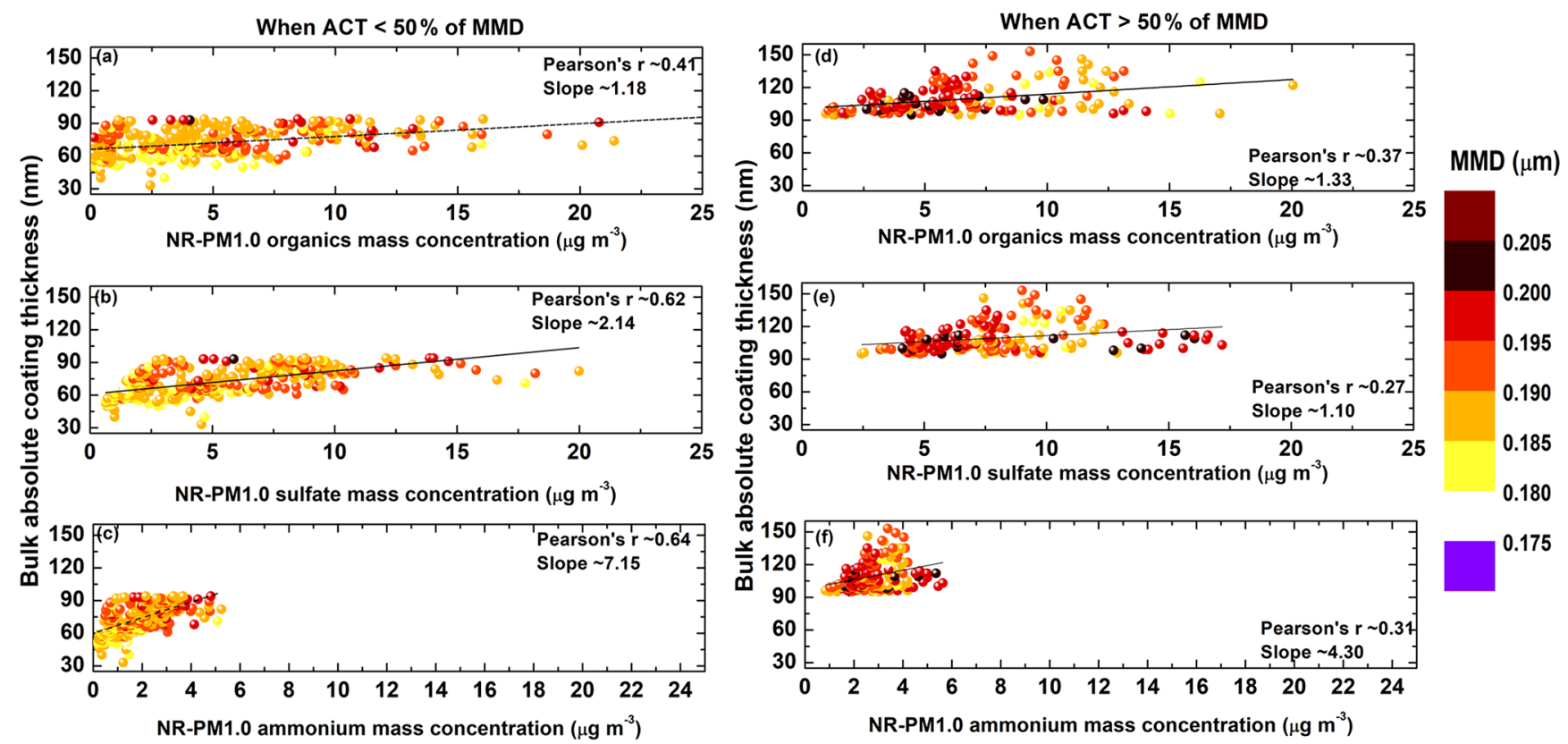

Figure 8. Scatter plot between the mass concentrations of non-refractory $\mathrm{PM}_{1.0}$ organics, sulfate, and ammonium aerosols and bulk absolute coating thickness during the ICARB-2018 for the observations with low ACT (a-c) and high ACT (d-f). Colour represents the corresponding mass median diameter value. Solid lines represent the linear least squares fit to the points. Regression slopes and correlation coefficients are written in each panel.

the association between the sum of mass concentrations of organics, sulfate, and ammonium aerosols and bulk absolute coating thickness over different sub-regions covered during the ICARB-2018. This reveals a very good association $(r \sim 0.90)$ over the remote EIO and a weak association over the NIO-E regions, whereas no association was found over the SEAS and NIO-W regions. It also advocates that variation in the submicron aerosol composition can explain alterations to $\mathrm{rBC}$ mixing state over the remote regions, whereas the $\mathrm{rBC}$ mixing state would be complex in the vicinity of the source regions. All these suggested the presence of distinct sources and atmospheric processes involving a range of condensing gaseous species contributing to the $\mathrm{BC}$ coating, altering its mixing state by enhancing the extent of the coating. However, it is not possible to precisely demarcate the sources and coating substances at the individual particle level with the present methodology using the SP2 and ACSM in tandem. It can be achieved through an instrument like a soot particle aerosol mass spectrometer (SP-AMS) (e.g., Gong et al., 2016; Liu et al., 2018). Alternatively, in situ morphological analysis techniques (like transmission electron microscope (TEM) equipped with an energy dispersive X-ray analyser) (Adachi et al., 2010, 2014; Ueda et al., 2016, 2018) are needed for the identification of particle-level morphology.

The present study focused on the characterization of refractory $\mathrm{BC}$ microphysical properties, including its mixing state information over the south-eastern Arabian Sea and the northern and equatorial Indian Ocean regions, which were in- fluenced by distinct outflow air masses (that originated over the east coast and/or Bay of Bengal, the west coast/peninsular India and marine regions and traversed over the oceanic regions). The sensitivity of the optical, hygroscopic properties of $\mathrm{BC}$ to these observed characteristics and the estimation of regional radiative and climatic implications due to such highly chemically aged, thickly coated large BC particles form the scope of future study.

\section{Summary and conclusions}

In the present study, the first-ever measurements of refractory BC microphysical properties (mass/number size distributions and mixing state parameters) over the oceanic regions adjacent to the Indian continent during periods of outflow were carried out as part of ICARB-2018. The major findings are the following:

1. The $\mathrm{rBC}$ mass concentrations were highest over the coastal region of the south-eastern Arabian Sea (mean $\sim 938 \pm 293 \mathrm{ng} \mathrm{m}^{-3}$ ), which received continental outflow directly from the western coast and/or peninsular India and dropped to the lowest concentrations over the remote EIO $\left(206 \pm 114 \mathrm{ng} \mathrm{m}^{-3}\right)$, where the impact of outflow was very weak. Nevertheless, the significant concentrations (mean $>500 \mathrm{ng} \mathrm{m}^{-3}$ ) observed over the NIO region, distant from the sources, highlighted the transport efficiency of the $\mathrm{rBC}$ and the widespread nature of the continental outflow. 
2. BC size distributions indicated a combination of sources and the BC core sizes corresponding to aged (temporally and/or chemically) continental outflow. Despite widely varied magnitudes of the $\mathrm{rBC}$ mass loading, the mass median diameter (MMD) values were in a narrow range of $0.18-0.21 \mu \mathrm{m}$ in all the regions due to the persistent outflow.

3. Importantly, the continental outflow from the Indian region to the adjacent oceans is characterized by thickly coated BC particles, which may have significant regional climatic implications. A great degree of coating on $\mathrm{rBC}$ particles and large variability of mixing state parameters was found over the SEAS region (median $\mathrm{RCT} \sim 2.15, \mathrm{ACT} \sim 109 \mathrm{~nm}$ ) that is greatly impacted by short-range continental outflow. The coating parameters showed a clear east-west contrast over the northern Indian Ocean with higher coatings and a narrow distribution over the NIO-E region $(\mathrm{RCT} \sim 2.05, \mathrm{ACT} \sim$ $104 \mathrm{~nm}$ ) where the east coast and/or the Bay of Bengal air masses prevailed, compared to the NIO-W (RCT 1.92, ACT $\sim 86 \mathrm{~nm}$ ) that received the west coast and/or peninsular India air masses. Observed lower coatings on rBC over the remote EIO $(\mathrm{RCT} \sim 1.73, \mathrm{ACT} \sim 69 \mathrm{~nm})$ suggested the possible role of preferential scavenging processes removing both internally mixed, large, thickly coated BC particles and potential condensable soluble material.

4. The average fraction of $\mathrm{rBC}$-containing particles $\left(F_{\mathrm{BC}}\right)$ was in the range of $0.08-0.12$ over different regions, which highlighted the presence of significant non-BC particles, especially over the coastal regions. Despite similar $\mathrm{rBC}$ core diameters (and the fraction of $\mathrm{rBC}$ containing particles) due to like sources, coated $\mathrm{BC}$ diameters varied according to the magnitude of the coating. The highest volume-weighted coated BC size $\left(D_{\mathrm{p}, \mathrm{v}}\right)$ values were seen over the SEAS (mean $\sim 0.41 \pm$ $0.04 \mu \mathrm{m})$ and the NIO-E (mean $\sim 0.41 \pm 0.01 \mu \mathrm{m})$, reflecting the vast extent of coating on $\mathrm{BC}$ in the air masses impacted by pollution outflow, compared to the EIO $(0.33 \pm 0.04 \mu \mathrm{m})$, which largely received marine air masses. Further, high values $(2.5-15)$ of the bulk mixing ratio of coating mass to $\mathrm{rBC}$ mass $\left(M_{\mathrm{R}, \text { bulk }}\right)$ were noticed in the outflow regions due to the presence of such thickly coated BC particles. Substantial $M_{\mathrm{R} \text {,bulk }}$ ( $\sim 4.24 \pm 1.45)$ values were found even over the EIO region, which may be associated with both emissions and atmospheric processes like chemical ageing contributing to non-refractory coatings on $\mathrm{rBC}$ particles.

5. Examination of the size-resolved BC mixing state revealed, unlike the studies reported over urban regions, the absence of any notable small BC with a thin coating (MMD $<0.18 \mu \mathrm{m}$ and ACT $<50 \mathrm{~nm}$ ) typically associated with traffic emissions. A significant proportion of moderately coated BC particles (with bulk ACT $50-100 \mathrm{~nm}$ ) with two different ranges of scattering enhancement $\left(E_{\mathrm{sca}} \sim 2-10\right.$ and $\left.\sim 10-100\right)$ were noticed due to the mixed nature of $\mathrm{BC}$ sources (a combination of solid fuel and fossil fuel emissions) in the outflow. Importantly, a higher proportion of thickly coated particles (ACT $>200 \mathrm{~nm}$ ) with $E_{\text {sca }}$ spanning over a wide range of 5-800 highlighted a distinct mixed source influence of the continental outflow from the Indian region to the surrounding oceanic regions.

6. The non-refractory sub-micrometre aerosol chemical composition in the continental outflow is mostly dominated by sulfate, except for the coastal regions where organics were also found in significant quantities. The association between the non-refractory mass concentrations of particulate less than $1 \mu \mathrm{m}$ in diameter (NR$\mathrm{PM}_{1.0}$ ) and bulk absolute coating thickness of $\mathrm{rBC}$ was weak for high ACT observations (seen in the proximity of sources), suggesting complex coatings. In contrast, for the $\mathrm{BC}$ population with low ACT values observed over the remote ocean where sulfate was the dominant NR-PM $M_{1.0}$ species, a significant correlation $(r \sim 0.62$; $p<0.01)$ was found between sulfate and $\mathrm{rBC}$ coating. 


\section{Appendix A: Symbols and abbreviations}

$\begin{array}{ll}\text { Symbols/abbreviations } & \text { Meaning } \\ \text { ACSM } & \text { Aerosol chemical speciation monitor } \\ \text { ACT } & \text { Absolute coating thickness } \\ D_{\mathrm{c}} & \text { BC core diameter } \\ D_{\mathrm{p}, \mathrm{v}} & \text { Volume-weighted coated BC size } \\ E_{\mathrm{sca}} & \text { Scattering enhancement } \\ \text { EIO } & \text { Equatorial Indian Ocean } \\ F_{\mathrm{BC}} & \text { Fraction of rBC-containing particles } \\ \text { ICARB } & \text { Integrated Campaign for Aerosols, gases and Radiation Budget } \\ \text { IGP } & \text { Indo-Gangetic Plain } \\ \text { MMD } & \text { Mass median diameter } \\ M_{\mathrm{R}, \text { bulk }} & \text { Bulk mixing ratio of coating mass over rBC mass } \\ \text { NIO } & \text { Northern Indian Ocean } \\ \text { NIO-E } & \text { Northern Indian Ocean (eastern leg) } \\ \text { NIO-W } & \text { Northern Indian Ocean (western leg) } \\ \text { NMD } & \text { Number median diameter } \\ \text { NR-PM } 1.0 & \text { Non-refractory PM } \\ \text { SAS } & \text { Southern Arabian Sea } \\ \text { SEAS } & \text { South-eastern Arabian Sea } \\ \text { SP2 } & \text { Single particle soot photometer } \\ \text { rBC } & \text { Refractory black carbon } \\ \text { RCT } & \text { Relative coating thickness } \\ \end{array}$


Data availability. Data are available upon request from the contact author, Surendran Nair Suresh Babu (sureshsplvssc@ gmail.com).

Supplement. The supplement related to this article is available online at: https://doi.org/10.5194/acp-21-9173-2021-supplement.

Author contributions. SNSB and SKK conceptualized the experiment and finalized the methodology. VSN, JV, SKK, MMG, and SNSB were involved in data collection onboard the ship. SKK carried out the scientific analysis of the data and was supported by MF and DL. SKK drafted the manuscript. SNSB, SKS, KKM, and HC reviewed and edited the manuscript.

Competing interests. The authors declare that they have no conflict of interest.

Special issue statement. This article is part of the special issue "Interactions between aerosols and the South West Asian monsoon". It is not associated with a conference.

Acknowledgements. The ICARB-2018 experiment was carried out under the ISRO Geosphere-Biosphere Programme. Authors acknowledge the National Centre for Polar and Ocean Research (NCPOR) of the Ministry of Earth Sciences, Government of India, for providing the shipboard facilities onboard ORV Sagar Kanya. We acknowledge the NOAA Air Resources Laboratory for the provision of the HYSPLIT transport and dispersion model and READY website (https://www.arl.noaa.gov/hysplit/ready/, last access: 20 September 2019) used in this study. We acknowledge the use of data and imagery from LANCE FIRMS operated by NASA's Earth Science Data and Information System (ESDIS) with funding provided by NASA Headquarters (http://earthdata. nasa.gov/firms, last access: 24 February 2020). Surendran Nair Suresh Babu acknowledges the Swarna Jayanti Fellowship from Department of Science Technology, Government of India for supporting the ACSM used in the study. TROPOMI retrieved tropospheric $\mathrm{NO}_{2}$ gridded data were obtained from http://www.temis.nl/ airpollution/no2col/no2regio_tropomi.php (last access: 27 February 2020) ERA-Interim wind data from ECMWF (European Centre for Medium range Weather Forecasting; https://apps.ecmwf.int/ datasets/data/interim-full-daily/levtype $=$ sfc/, last access: 25 February 2020) are acknowledged. Hugh Coe acknowledges support from NERC. Sreedharan Krishnakumari Satheesh would like to thank SERB-DST for the J.C. Bose Fellowship and "Tata Education and Development Trust" for the support.

Financial support. Hugh Coe has been supported from NERC (grant no. NE/L013886/1).

Review statement. This paper was edited by Andreas Petzold and reviewed by two anonymous referees.

\section{References}

Adachi, K., Chung, S. H., and Buseck, P. R.: Shapes of soot aerosol particles and implications for their effects on climate, J. Geophys. Res.-Atmos., 115, D15206, https://doi.org/10.1029/2009JD012868, 2010.

Adachi, K., Zaizen, Y., Kajino, M., and Igarashi, Y.: Mixing state of regionally transported soot particles and the coating effect on their size and shape at a mountain site in Japan, J. Geophys. Res.-Atmos., 119, 5386-5396, https://doi.org/10.1002/2013JD020880, 2014.

Allan, J., Jimenez, J., Williams, P., Alfarra, M., Bower, K., Jayne, J., Coe, H., and Worsnop, D.: Quantitative sampling using an Aerodyne aerosol mass spectrometer: 1 . Techniques of data interpretation and error analysis, J. Geophys. Res.-Atmos., 108, 4090, https://doi.org/10.1029/2003JD001607, 2003.

Allan, J., Delia, A. E., Coe, H., Bower, K. N., Alfrarra, R., Jimenez, J. L., Middlebrook, A. M., Drewnick, F., Onasch, T. B., Canagaratna, M. R., Jayne, J., and Worsnop, D. R.: Technical note: a generalised method for the extraction of chemically resolved mass spectra from Aerodyne aerosol mass spectrometer data, J. Aerosol Sci., 35, 909-922, https://doi.org/10.1016/j.jaerosci.2004.02.007, 2004.

Asnani, G. C.: Tropical Meteorology, Vol.1 and Vol.2, Indian Institute of Tropical Meteorology, Pashan, Pune, 1012 pp., 1993.

Aswini A. R., Hegde P., Aryasree S., Girach I. A., and Nair P. R.: Continental outflow of anthropogenic aerosols over Arabian Sea and Indian Ocean during wintertime: ICARB-2018 campaign, Sci. Total Environ., 712, 135214 https://doi.org/10.1016/j.scitotenv.2019.135214, 2020.

Babu, S. S., Moorthy, K. K., Manchanda, R. K., Sinha, P. R., Satheesh, S. K., Vajja, D. P., Srinivasan, S., and Kumar, V. H. A.: Free tropospheric black carbon aerosol measurements using high altitude balloon: Do BC layers build their own homes up in the atmosphere?, Geophys. Res. Lett., 38, L08803, https://doi.org/10.1029/2011GL046654, 2011.

Babu, S. S., Gogoi, M. M., Kumar, V. H. A., Nair, V. S., and Moorthy, K. K.: Radiative properties of Bay of Bengal aerosols: Spatial distinctiveness and source impacts, J. Geophys. Res., 117, D06213, https://doi.org/10.1029/2011JD017355, 2012.

Babu, S. S., Manoj, M. R., Moorthy, K. K., Gogoi, M. M., Nair, V. S., Kompalli, S. K., Satheesh, S. K., Niranjan, K., Ramagopal, K., Bhuyan, P. K., and Singh, D.: Trends in aerosol optical depth over Indian region: Potential causes and impact indicators, J. Geophys. Res., 118, 11794-11806, 2013.

Bollasina, M., Nigam, S., and Lau, K.-M.: Absorbing Aerosols and Summer Monsoon Evolution over South Asia: An Observational Portrayal, J. Climate, 21, 3221-3239, https://doi.org/10.1175/2007JCLI2094.1, 2008.

Bond, T. C. and Bergstrom, R. W.: Light absorption by carbonaceous particles: An investigative review, Aerosol Sci. Tech., 40, 27-67, https://doi.org/10.1080/02786820500421521, 2006.

Bond, T. C., Doherty, S. J., Fahey, D. W., Forster, P. M., Berntsen, T., De Angelo, B. J., Flanner, M. G., Ghan, S., Karcher, B., Koch, D., Kinne, S., Kondo, Y., Quinn, P. K., Sarofim, M. C., Schultz, M. G., Schulz, M., Venkataraman, C., Zhang, H., Zhang, S., Bellouin, N., Guttikunda, S. K., Hopke, P. K., Jacobson, M. Z., Kaiser, J. W., Klimont, Z., Lohmann, U., Schwarz, J. P., Shindell, D., Storelvmo, T., Warren, S. G., and Zender, C. S.: Bounding the role of black carbon in the climate system: A sci- 
entific assessment, J. Geophys. Res.-Atmos., 118, 5380-5552, https://doi.org/10.1002/jgrd.50171, 2013.

Boos, W. R. and Storelvmo, T.: Near-linear response of mean monsoon strength to a broad range of radiative forcings, P. Natl. Acad. Sci. USA, 113, 1510-1515, https://doi.org/10.1073/pnas.1517143113, 2016.

Brooks, J., Liu, D., Allan, J. D., Williams, P. I., Haywood, J., Highwood, E. J., Kompalli, S. K., Babu, S. S., Satheesh, S. K., Turner, A. G., and Coe, H.: Black carbon physical and optical properties across northern India during pre-monsoon and monsoon seasons, Atmos. Chem. Phys., 19, 13079-13096, https://doi.org/10.5194/acp-19-13079-2019, 2019.

Budisulistiorini, S. H., Baumann, K., Edgerton, E. S., Bairai, S. T., Mueller, S., Shaw, S. L., Knipping, E. M., Gold, A., and Surratt, J. D.: Seasonal characterization of submicron aerosol chemical composition and organic aerosol sources in the southeastern United States: Atlanta, Georgia,and Look Rock, Tennessee, Atmos. Chem. Phys., 16, 5171-5189, https://doi.org/10.5194/acp16-5171-2016, 2016.

Canagaratna, M., Jayne, J., Jimenez, J., Allan, J., Alfarra, M., Zhang, Q., Onasch, T., Drewnick, F., Coe, H., Middlebrook, A., Delia, A., Williams, L., Trimborn, A., Northway, M., DeCarlo, P., Kolb, C., Davidovits, P., and Worsnop, D.: Chemical and microphysical characterisation of ambient aerosols with the Aerodyne aerosol mass spectrometer, Mass Spectrom. Rev., 26, 185-222, https://doi.org/10.1002/Mas.20115, 2007.

Cappa, C. D., Onasch, T. B., Massoli, P., Worsnop, D. R., Bates, T. S., Cross, E. S., Davidovits, P., Hakala, J., Hayden, K. L., Jobson, B. T., Kolesar, K. R., Lack, D. A., Lerner, B. M., Li, S.-M., Mellon, D., Nuaaman, I., Olfert, J. S., Petäjä, T., Quinn, P. K., Song, C., Subramanian, R., Williams, E. J., and Zaveri, R. A.: Radiative Absorption Enhancements Due to the Mixing State of Atmospheric Black Carbon, Science, 337, 1078-1081, https://doi.org/10.1126/science.1223447, 2012.

Cappa, C. D., Zhang, X., Russell, L. M., Collier, S., Lee, A. K. Y., Chen, C.-L., Betha, R., Chen, S., Liu, J., Price, D. J., Sanchez, K. J., McMeeking, G. R., Williams, L. R., Onasch, T. B., Worsnop, D. R., Abbatt, J., and Zhang, Q.: Light absorption by ambient black and brown carbon and its dependence on black carbon coating state for two California, USA, cities in winter and summer, J. Geophys. Res.-Atmos., 124, 1550-1577, https://doi.org/10.1029/2018JD029501, 2019.

Chen, C., Fan, X., Shaltout, T., Qiu, C., Ma, Y., Goldman, A., and Khalizov, A. F.: An unexpected restructuring of combustion soot aggregates by subnanometer coatings of polycyclic aromatic hydrocarbons, Geophys. Res. Lett., 43, 11080-11088, https://doi.org/10.1002/2016GL070877, 2016.

Chen, C., Enekwizu, O. Y., Fan, X., Dobrzanski, C. D., Ivanova, E. V., Ma, Y., Gor, G. Y., and Khalizov, A. F.: Single parameter for predicting the morphology of atmospheric black carbon, Environ. Sci. Technol., 52, 14169-14179, https://doi.org/10.1021/acs.est.8b04201, 2018.

Cheng, Y., Li, S.-M., Gordon, M., and Liu, P.: Size distribution and coating thickness of black carbon from the Canadian oil sands operations, Atmos. Chem. Phys., 18, 2653-2667, https://doi.org/10.5194/acp-18-2653-2018, 2018.

Clarke, A. D. and Kapustin, V. N.: A Pacific aerosol survey: I. A decade of data on particle production, transport, evolution, and mixing in the troposphere, J. At- mos. Sci., 59, 363-382, https://doi.org/10.1175/1520 0469(2002)059<0363:APASPI>2.0.CO;2, 2002.

Darbyshire, E., Morgan, W. T., Allan, J. D., Liu, D., Flynn, M. J., Dorsey, J. R., O’Shea, S. J., Lowe, D., Szpek, K., Marenco, F., Johnson, B. T., Bauguitte, S., Haywood, J. M., Brito, J. F., Artaxo, P., Longo, K. M., and Coe, H.: The vertical distribution of biomass burning pollution over tropical South America from aircraft in situ measurements during SAMBBA, Atmos. Chem. Phys., 19, 5771-5790, https://doi.org/10.5194/acp19-5771-2019, 2019.

Das, P. K.: The Monsoons, 5th IMO Lecture, WMO Rep. 613, World Meteorol. Org., Geneva, 1986.

DeCarlo, P. F., Ulbrich, I. M., Crounse, J., de Foy, B., Dunlea, E. J., Aiken, A. C., Knapp, D., Weinheimer, A. J., Campos, T., Wennberg, P. O., and Jimenez, J. L.: Investigation of the sources and processing of organic aerosol over the Central Mexican Plateau from aircraft measurements during MILAGRO, Atmos. Chem. Phys., 10, 5257-5280, https://doi.org/10.5194/acp10-5257-2010, 2010.

Ditas, J., Ma, N., Zhang, Y., Assmann, D., Neumaier, M., Riede, H., Karu, E., Williams, J., Scharffe, D., Wang, Q., Saturno, J., Schwarz, J. P., Katich, J. M., McMeeking, G. R., Zahn, A., Hermann, M., Brenninkmeijer, C. A., Andreae, M. O., Pöschl, U., Su, H., and Cheng, Y.: Strong impact of wildfires on the abundance and aging of black carbon in the lowermost stratosphere, P. Natl. Acad. Sci. USA, 115, E11595-E11603, https://doi.org/10.1073/pnas.1806868115, 2018.

Donahue, N. M., Robinson, A. L., Stanier, C. O., and Pandis, S. N.: Coupled partitioning, dilution, and chemical aging of semivolatile organics, Environ. Sci. Technol., 40, 2635-2643, 2006.

D’Errico, M., Cagnazzo, C., Fogli, P. G., Lau, W. K. M., von Hardenberg, J., Fierli, F., and Cherchi, A.: Indian monsoon and the elevated-heat-pump mechanism in a coupled aerosol climate model, J. Geophys. Res.-Atmos., 120, 8712-8723, https://doi.org/10.1002/2015JD023346, 2015.

Gao, R. S., Schwarz, J. P., Kelly, K. K., Fahey, D. W., Watts, L. A., Thompson, T. L., Spackman, J. R., Slowik, J. G., Cross, E. S., Han, J. H., Davidovits, P., Onasch, T. B., and Worsnop, D. R.: A novel method for estimating light-scattering properties of soot aerosols using a modified single-particle soot photometer, Aerosol Sci. Tech., 41, 125-135, 2007.

Gogoi, M. M., Rao C. T., Jayachandran, V., Kompalli, S. K., Nair, V. S., Rama Gopal, K., and Babu, S. S.: Spatial gradient of aerosol mass concentrations and size distributions over southeastern Arabian Sea and equatorial Indian Ocean during ICARB-2018, Atmos. Environ., 213, 727-738, https://doi.org/10.1016/j.atmosenv.2019.06.038, 2019.

Gong, X., Zhang, C., Chen, H., Nizkorodov, S. A., Chen, J., and Yang, X.: Size distribution and mixing state of black carbon particles during a heavy air pollution episode in Shanghai, Atmos. Chem. Phys., 16, 5399-5411, https://doi.org/10.5194/acp16-5399-2016, 2016.

Gustafsson, Ö., Krusa, M., Zencak, Z., Sheesley, R. J., Granat, L., Engstrom, E., Praveen, P. S., Rao, P. S. P., Leck, C., and Rodhe, H.: Brown clouds over south Asia: Biomass or fossil fuel combustion?, Science, 323, 495-498, https://doi.org/10.1126/science.1164857, 2009. 
Hallquist, M., Wenger, J. C., Baltensperger, U., Rudich, Y., Simpson, D., Claeys, M., Dommen, J., Donahue, N. M., George, C., Goldstein, A. H., Hamilton, J. F., Herrmann, H., Hoffmann, T., Iinuma, Y., Jang, M., Jenkin, M. E., Jimenez, J. L., Kiendler-Scharr, A., Maenhaut, W., McFiggans, G., Mentel, Th. F., Monod, A., Prévôt, A. S. H., Seinfeld, J. H., Surratt, J. D., Szmigielski, R., and Wildt, J.: The formation, properties and impact of secondary organic aerosol: current and emerging issues, Atmos. Chem. Phys., 9, 5155-5236, https://doi.org/10.5194/acp9-5155-2009, 2009.

Hu, W. W., Campuzano-Jost, P., Day, D. A., Croteau, P., Canagaratna, M. R., Jayne, J. T., Worsnop, D. R., and Jimenez, J. L.: Evaluation of the new capture vapourizer for aerosol mass spectrometers (AMS) through laboratory studies of inorganic species, Atmos. Meas. Tech., 10, 2897-2921, https://doi.org/10.5194/amt-10-2897-2017, 2017a.

Hu, W. W., Campuzano-Jost, P., Day, D. A., Croteau, P., Canagaratna, M. R., Jayne, J. T., Worsnop, D. R., and Jimenez, J. L.: Evaluation of the new capture vaporizer for aerosol mass spectrometers (AMS) through field studies of inorganic species, Aerosol Sci. Tech., 51, 735-754, https://doi.org/10.1080/02786826.2017.1296104, 2017b.

Huang, X., Ding, A., Liu, L., Liu, Q., Ding, K., Niu, X., Nie, W., Xu, Z., Chi, X., Wang, M., Sun, J., Guo, W., and Fu, C.: Effects of aerosol-radiation interaction on precipitation during biomassburning season in East China, Atmos. Chem. Phys., 16, 10063 10082, https://doi.org/10.5194/acp-16-10063-2016, 2016.

IPCC: Climate Change., The Physical Science Basis. Contribution of Working Group I to the Fifth Assessment Report of the Intergovernmental Panel on Climate Change, edited by: Stocker, T. F., Qin, D., Plattner, G.-K., Tignor, M., Allen, S. K., Boschung, J., Nauels, A., Xia, Y., Bex, V., and Midgley, P. M., Cambridge University Press, Cambridge, United Kingdom and New York, NY, USA, 1535 pp., 2013.

Ivanova, E. V., Khalizov, A. F., and Gor, G. Y.: Kinetic model for competitive condensation of vapor between concave and convex surfaces in a soot aggregate, Aerosol Sci. Tech., 55, 302-315, https://doi.org/10.1080/02786826.2020.1846677, 2021.

Jacobson, M. Z.: Strong Radiative Heating Due to the Mixing State of Black Carbon in Atmospheric Aerosols, Nature, 409, 695697, 2001.

Jayne, J. T., Leard, D. C., Zhang, X. F., Davidovits, P., Smith, K. A., Kolb, C. E., and Worsnop, D. R.: Development of an aerosol mass spectrometer for size and composition analysis of submicron particles, Aerosol Sci. Tech., 33, 49-70, 2000.

Jimenez, J. L., Jayne, J. T., Shi, Q., Kolb, C. E., Worsnop, D. R., Yourshaw, I., Seinfeld, J. H., Flagan, R. C., Zhang, X. F., Smith, K. A., Morris, J. W., and Davidovits, P.: Ambient aerosol sampling using the Aerodyne Aerosol Mass Spectrometer, J. Geophys. Res.-Atmos., 108, 8425, https://doi.org/10.1029/2001JD001213, 2003.

Khalizov, A. F., Zhang, R., Zhang, D., Xue, H., Pagels, J., and McMurry, P. H.: Formation of highly hygroscopic soot aerosols upon internal mixing with sulfuric acid vapor, J. Geophys. Res.-Atmos., 114, D05208, 1-15, https://doi.org/10.1029/2008JD010595, 2009.

Ko, J., Krasowsky, T., and Ban-Weiss, G.: Measurements to determine the mixing state of black carbon emitted from the 20172018 California wildfires and urban Los Angeles, Atmos. Chem.
Phys., 20, 15635-15664, https://doi.org/10.5194/acp-20-156352020, 2020.

Kompalli, S. K., Babu, S. S., Moorthy, K. K., Gogoi, M. M., Nair, V. S., and Chaubey, J. P.: Seasonal variation of aerosol black carbon distribution over the Bay of Bengal: multi-campaign measurements, Atmos. Environ., 64, 366-373, https://doi.org/10.1016/j.atmosenv.2012.09.073, 2013.

Kompalli, S. K., Babu, S. S., Moorthy, K. K., Manoj, M. R., Kirankumar, N. V. P., Shaeb, K. H. B., and Joshi, A.: Aerosol black carbon characteristics over central India: temporal variation and its dependence on mixed layer height, Atmos. Res., 147-148, 27-37, https://doi.org/10.1016/j.atmosres.2014.04.015, 2014a.

Kompalli, S. K., Moorthy, K. K., and Babu, S. S.: Rapid response of atmospheric $\mathrm{BC}$ to anthropogenic sources: observational evidence, Atmos. Sci. Lett., 15, 166-171, https://doi.org/10.1002/as12.483, 2014b.

Kompalli, S. K., Nair, V. S., Jayachandran, V., Gogoi, M. M., and Babu, S. S.: Particle number size distributions and new particle formation events over the northern Indian Ocean during continental outflow, Atmos. Environ., 238, 117719, https://doi.org/10.1016/j.atmosenv.2020.117719, 2020a.

Kompalli, S. K., Suresh Babu, S. N., Satheesh, S. K., Krishna Moorthy, K., Das, T., Boopathy, R., Liu, D., Darbyshire, E., Allan, J. D., Brooks, J., Flynn, M. J., and Coe, H.: Seasonal contrast in size distributions and mixing state of black carbon and its association with $\mathrm{PM}_{1.0}$ chemical composition from the eastern coast of India, Atmos. Chem. Phys., 20, 3965-3985, https://doi.org/10.5194/acp-20-3965-2020, 2020 b.

Kondo, Y., Matsui, H., Moteki, N., Sahu, L., Takegawa, N., Kajino, M., Zhao, Y., Cubison, M. J., Jimenez, J. L., Vay, S., Diskin, G. S., Anderson, B., Wisthaler, A., Mikoviny, T., Fuelberg, H. E., Blake, D. R., Huey, G., Weinheimer, A. J., Knapp, D. J., and Brune, W. H.: Emissions of black carbon, organic, and inorganic aerosols from biomass burning in North America and Asia in 2008, J. Geophys. Res., 116, D08204, https://doi.org/10.1029/2010JD015152, 2011.

Köylü, Ü. Ö., Faeth, G. M., Farias, T. L., and Carvalho, M. G.: Fractal and projected structure properties of soot aggregates, Combust. Flame, 100, 621-633, https://doi.org/10.1016/00102180(94)00147-K, 1995.

Krasowsky, T. S., McMeeking, G. R., Sioutas, C., and Ban-Weiss, G.: Characterizing the evolution of physical properties and mixing state of black carbon particles: from near a major highway to the broader urban plume in Los Angeles, Atmos. Chem. Phys., 18, 11991-12010, https://doi.org/10.5194/acp-18-119912018, 2018.

Kütz, S. and Schmidt-Ott, A.: Characterization of agglomerates by condensation-induced restructuring, J. Aerosol Sci., 23, 357360, https://doi.org/10.1016/0021-8502(92)90423-S, 1992.

Laborde, M., Mertes, P., Zieger, P., Dommen, J., Baltensperger, U., and Gysel, M.: Sensitivity of the Single Particle Soot Photometer to different black carbon types, Atmos. Meas. Tech., 5, 10311043, https://doi.org/10.5194/amt-5-1031-2012, 2012.

Laborde, M., Crippa, M., Tritscher, T., Jurányi, Z., Decarlo, P. F., Temime-Roussel, B., Marchand, N., Eckhardt, S., Stohl, A., Baltensperger, U., Prévôt, A. S. H., Weingartner, E., and Gysel, M.: Black carbon physical properties and mixing state in the European megacity Paris, Atmos. Chem. Phys., 13, 5831-5856, https://doi.org/10.5194/acp-13-5831-2013, 2013. 
Lambe, A. T., Cappa, C. D., Massoli, P., Onasch, T. B., Forestieri, S. D., Martin, A. T., Cummings, M. J., Croasdale, D. R., Brune, W. H., Worsnop, D. R., and Davidovits, P.: Relationship between oxidation level and optical properties of secondary organic aerosol, Environ. Sci. Technol., 47, 6349-6357, 2013.

Lawrence, M. G. and Lelieveld, J.: Atmospheric pollutant outflow from southern Asia: a review, Atmos. Chem. Phys., 10, 1101711096, https://doi.org/10.5194/acp-10-11017-2010, 2010.

Liu, D., Flynn, M., Gysel, M., Targino, A., Crawford, I., Bower, K., Choularton, T., Jurányi, Z., Steinbacher, M., Hüglin, C., Curtius, J., Kampus, M., Petzold, A., Weingartner, E., Baltensperger, U., and Coe, H.: Single particle characterization of black carbon aerosols at a tropospheric alpine site in Switzerland, Atmos. Chem. Phys., 10, 7389-7407, https://doi.org/10.5194/acp10-7389-2010, 2010.

Liu, D., Allan, J., Whitehead, J., Young, D., Flynn, M., Coe, H., McFiggans, G., Fleming, Z. L., and Bandy, B.: Ambient black carbon particle hygroscopic properties controlled by mixing state and composition, Atmos. Chem. Phys., 13, 2015-2029, https://doi.org/10.5194/acp-13-2015-2013, 2013.

Liu, D., Allan, J. D., Young, D. E., Coe, H., Beddows, D., Fleming, Z. L., Flynn, M. J., Gallagher, M. W., Harrison, R. M., Lee, J., Prevot, A. S. H., Taylor, J. W., Yin, J., Williams, P. I., and Zotter, P.: Size distribution, mixing state and source apportionment of black carbon aerosol in London during wintertime, Atmos. Chem. Phys., 14, 10061-10084, https://doi.org/10.5194/acp-1410061-2014, 2014

Liu, D., Whitehead, J., Alfarra, M. R., Reyes-Villegas, E., Spracklen, D. V., Reddington, C. L., Kong, S., Williams, P. I., Ting, Y.-C., Haslett, S., Taylor, J. W., Flynn, M. J., Morgan, W. T., McFiggans, G., Coe, H., and Allan, J. D.: Black-carbon absorption enhancement in the atmosphere determined by particle mixing state, Nat. Geosci., 10, 184-188, https://doi.org/10.1038/ngeo2901, 2017.

Liu, D., Taylor, J. W., Crosier, J., Marsden, N., Bower, K. N., Lloyd, G., Ryder, C. L., Brooke, J. K., Cotton, R., Marenco, F., Blyth, A., Cui, Z., Estelles, V., Gallagher, M., Coe, H., and Choularton, T. W.: Aircraft and ground measurements of dust aerosols over the west African coast in summer 2015 during ICE-D and AER-D, Atmos. Chem. Phys., 18, 3817-3838, https://doi.org/10.5194/acp-18-3817-2018, 2018.

Liu, D., Joshi, R., Wang, J., Yu, C., Allan, J. D., Coe, H., Flynn, M. J., Xie, C., Lee, J., Squires, F., Kotthaus, S., Grimmond, S., Ge, X., Sun, Y., and Fu, P.: Contrasting physical properties of black carbon in urban Beijing between winter and summer, Atmos. Chem. Phys., 19, 6749-6769, https://doi.org/10.5194/acp19-6749-2019, 2019.

Liu, P. S. K., Deng, R., Smith, K. A., Williams, L. R., Jayne, J. T., Canagaratna, M. R., Moore, K., Onasch, T. B., Worsnop, D. R., and Deshler, T.: Transmission efficiency of an aerodynamic focusing lens system: comparison of model calculations and laboratory measurements for the Aerodyne Aerosol Mass Spectrometer, Aerosol. Sci. Tech., 41, 721-733, 2007.

Liu, S., Aiken, A. C., Gorkowski, K., Dubey, M. K., Cappa, C. D., Williams, L. R., Herndon, S. C., Massoli, P., Fortner, E. C., Chhabra, P. S., Brooks, W. A., Onasch, T. B., Jayne, J. T., Worsnop, D. R., China, S., Sharma, N., Mazzoleni, C., Xu, L., Ng, N. L., Liu, D., Allan, J. D., Lee, J. D., Fleming, Z. L., Mohr, C., Zotter, P., Szidat, S., and Prévôt, A.
S. H.: Enhanced light absorption by mixed source black and brown carbon particles in UK winter, Nat. Commun., 6, 8435, https://doi.org/10.1038/ncomms9435, 2015.

Leith, D. and Peters, T. M.: Concentration Measurement and Counting Efficiency of the Aerodynamic Particle Sizer 3321, J. Aerosol Sci., 34, 627-634, 2003.

Lund, M. T., Samset, B. H., Skeie, R. B., Watson-Parris, D., Katich, J. M., Schwarz, J. P., and Weinzierl, B.: Short black carbon lifetime inferred from a global set of aircraft observations, npj Climate and Atmospheric Science, 1, 1-8. https://doi.org/10.1038/s41612-018-0040-x, 2018.

McFiggans, G., Alfarra, M. R., Allan, J. D., Coe, H., Hamilton, J. F., Harrison, R. M., Jenkin, M. E., Lewis, A. C., Moller, S. J., and Williams, P. I.: A review of the state-of-the-science relating to secondary particulate matter of relevance to the composition of the UK atmosphere, Full technical report to Defra, project AQ0732, 2015.

McMeeking, G. R., Hamburger, T., Liu, D., Flynn, M., Morgan, W. T., Northway, M., Highwood, E. J., Krejci, R., Allan, J. D., Minikin, A., and Coe, H.: Black carbon measurements in the boundary layer over western and northern Europe, Atmos. Chem. Phys., 10, 9393-9414, https://doi.org/10.5194/acp10-9393-2010, 2010.

McMeeking, G. R., Morgan, W. T., Flynn, M., Highwood, E. J., Turnbull, K., Haywood, J., and Coe, H.: Black carbon aerosol mixing state, organic aerosols and aerosol optical properties over the United Kingdom, Atmos. Chem. Phys., 11, 9037-9052, https://doi.org/10.5194/acp-11-9037-2011, 2011.

Meehl, G. A., Arblaster, J. M., and Collins, W. D.: Effects of black carbon aerosols on the Indian monsoon, J. Climate, 21, 28692882, 2008.

Meng, C. C., Wang, L. T., Zhang, F. F., Wei, Z., Ma, S. M., Ma, X., Yang, J.: Characteristics of concentrations and water-soluble inorganic ions in $\mathrm{PM}_{2.5}$ in Handan City, Hebei province, China, Atmos. Res., 171, 133-146, 2016.

Menon, S., Hansen, J., Nazarenko, L., and Luo, Y. F.: Climate effects of black carbon aerosols in China and India, Science, 297, 2250-2253, 2002.

Metcalf, A. R., Craven, J. S., Ensberg, J. J., Brioude, J., Angevine, W., Sorooshian, A., Duong, H. T., Jonsson, H. H., Flagan, R. C., and Seinfeld, J. H.: Black carbon aerosol over the Los Angeles Basin during CalNex, J. Geophys. Res., 117, D00V13, https://doi.org/10.1029/2011jd017255, 2012.

Middlebrook, A. M., Bahreini, R., Jimenez, J. L., and Canagaratna, M. R.: Evaluation of Composition-Dependent Collection Efficiencies for the Aerodyne Aerosol Mass Spectrometer using Field Data, Aerosol Sci. Tech., 46, 258-271, https://doi.org/10.1080/02786826.2011.620041, 2012.

Miyakawa, T., Oshima, N., Taketani, F., Komazaki, Y., Yoshino, A., Takami, A., Kondo, Y., and Kanaya, Y.: Alteration of the size distributions and mixing states of black carbon through transport in the boundary layer in east Asia, Atmos. Chem. Phys., 17, 58515864, https://doi.org/10.5194/acp-17-5851-2017, 2017.

Moffet, R. C. and Prather, K. A.: In-situ measurements of the mixing state and optical properties of soot with implications for radiative forcing estimates, PNAS, 106, 11872-11877, 2009.

Molina, M. J., Ivanov, A. V., Trakhtenberg, S., and Molina, L. T.: Atmospheric evolution of organic aerosol, Geophys. Res. Lett., 31, L22104, https://doi.org/10.1029/2004g1020910, 2004. 
Moorthy, K. K., Sunilkumar, S. V., Pillai, P. S., Parameswaran, K., Nair, P. R., Ahmed, Y. N., Ramgopal, K., Narasimhulu, K., Reddy, R. R., Vinoj, V., Satheesh, S. K., Niranjan, K., Rao, B. M., Brahmanandam, P. S., Saha, A., Badarinath, K. V. S., Kiranchand, T. R., and Latha, K. M.: Wintertime spatial characteristics of boundary layer aerosols over peninsular India, J. Geophys. Res., 110, D08207, https://doi.org/10.1029/2004JD005520, 2005.

Moorthy, K. K., Satheesh, S. K., Babu, S. S., and Dutt, C. B. S.: Integrated campaign for aerosols, gases, and radiation budget (ICARB): an overview, J. Earth Syst. Sci., 117, 243-262, 2008.

Moorthy, K. K., Satheesh, S. K., Sarin, M. M., and Panday, A. K.: South Asian aerosols in perspective: Preface to the special issue, Atmos. Environ., 125, 307-311, https://doi.org/10.1016/j.atmosenv.2015.10.073, 2016.

Moteki, N. and Kondo, Y.: Effects of mixing state on black carbon measurements by laser-induced incandescence, Aerosol Sci. Tech., 41, 398-417, 2007.

Moteki, N. and Kondo, Y.: Dependence of laser-induced incandescence on physical properties of black carbon aerosols: Measurements and theoretical interpretation, Aerosol Sci. Tech., 44, 663675,2010

Moteki, N., Kondo, Y., Miyazaki, Y., Takegawa, N., Komazaki, Y., Kurata, G., Shirai, T., Blake, D., Miyakawa, T., and Koike, M.: Evolution of mixing state of black carbon particles: Aircraft measurements over the western Pacific in March 2004, Geophys. Res. Lett., 34, L11803, https://doi.org/10.1029/2006GL028943, 2007.

Moteki, N., Kondo, Y., and Nakamura, S.: Method to measure refractive indices of small nonspherical particles: Application to black carbon particles, J. Aerosol Sci., 41, 513-521, https://doi.org/10.1016/j.jaerosci.2010.02.013, 2010.

Nair, V. S., Jayachandran, V. N., Kompalli, S. K., Gogoi, M. M., and Babu, S. S.: Cloud condensation nuclei properties of South Asian outflow over the northern Indian Ocean during winter, Atmos. Chem. Phys., 20, 3135-3149, https://doi.org/10.5194/acp20-3135-2020, 2020.

Ng, N. L., Herndon, S. C., Trimborn, A., Canagaratna, M. R., Croteau, P. L., Onasch, T. B., Sueper, D., Worsnop, D. R., Zhang, Q. , Sun, Y. L., and Jayne, J. T.: An Aerosol Chemical Speciation Monitor (ACSM) for Routine Monitoring of the Composition and Mass Concentrations of Ambient Aerosol, Aerosol Sci. Tech., 45, 780-794, https://doi.org/10.1080/02786826.2011.560211, 2011.

Pagels, J., Khalizov, A. F., McMurry, P. H., and Zhang, R. Y.: Processing of Soot by Controlled Sulphuric Acid and Water Condensation Mass and Mobility Relationship, Aerosol Sci. Tech., 43, 629-640, https://doi.org/10.1080/02786820902810685, 2009.

Pandey, A., Sadavarte, P., Rao, A. B., and Venkataraman, C.: Trends in multi-pollutant emissions from a technology-linked inventory for India: II. Residential, agricultural and informal industry sectors, Atmos. Environ., 99, 341-352, 2014.

Park, K., Kittelson, D., Zachariah, M., and McMurry, P.: Measurement of Inherent Material Density of Nanoparticle Agglomerates, J. Nanopart. Res., 6, 267-272, https://doi.org/10.1023/B:NANO.0000034657.71309.e6, 2004.

Peng, J., Hu, M., Guo, S., Du, Z., Zheng, J., Shang, D., Levy Zamora, M., Zeng, L., Shao, M., Wu, Y.-S., Zheng, J., Wang, Y., Glen, C. R., Collins, D. R., Molina, M. J., and Zhang, R.: Markedly enhanced absorption and di- rect radiative forcing of black carbon under polluted urban environments, P. Natl. Acad. Sci. USA, 113, 4266-4271, https://doi.org/10.1073/pnas.1602310113, 2016.

Petzold, A., Ogren, J. A., Fiebig, M., Laj, P., Li, S.-M., Baltensperger, U., Holzer-Popp, T., Kinne, S., Pappalardo, G., Sugimoto, N., Wehrli, C., Wiedensohler, A., and Zhang, X.-Y.: Recommendations for reporting "black carbon" measurements, Atmos. Chem. Phys., 13, 8365-8379, https://doi.org/10.5194/acp13-8365-2013, 2013.

Prasad, P., Ramana, R., Venkat Ratnam, M., Chen, W., Vijaya Bhaskara Rao, S., Gogoi, M. M., Kompalli, S. K., Kumar, K. S., and Babu, S. S.: Characterization of atmospheric Black Carbon over a semi-urban site of Southeast India: Local sources and long-range transport, Atmos. Res., 213, 411-421, https://doi.org/10.1016/j.atmosres.2018.06.024, 2018.

Ramanathan, V. and Carmichael, G.: Global and regional climate changes due to black carbon, Nat. Geosci., 1, 221-227, 2008.

Ramanathan, V., Crutzen, P. J., Lelieveld, J., Mitra, A. P., Althausen, D., Anderson, J., Andreae, M. O., Cantrell, W., Cass, G. R., Chung, C. E., Clarke, A. D., Coakley, J. A., Collins, W. D., Conant, W. C., Dulac, F., Heintzenberg, J., Heymsfield, A. J., Holben, B., Howell, S., Hudson, J., Jayaraman, A., Kiehl, J. T., Krishnamurti, T. N., Lubin, D., McFarquhar, G., Novakov, T., Ogren, J. A., Podgorny, I. A., Prather, K., Priestley, K., Prospero, J. M., Quinn, P. K., Rajeev, K., Rasch, P., Rupert, S., Sadourny, R., Satheesh, S. K., Shaw, G. E., Sheridan, P., and Valero, F. P. J.: Indian Ocean Experiment: An integrated analysis of the climate forcing and effects of the greatIndo-Asian haze, J. Geophys. Res., 106, 28371-28398, https://doi.org/10.1029/2001JD900133, 2001.

Ramanathan, V., Chung, C., Kim, D., Bettge, T., Buja, L., Kiehl, J. T., Washington, W. M., Fu, Q., Sikka, D. R., and Wild, M.: Atmospheric brown clouds: Impacts on South Asian climate and hydrological cycle, P. Natl. Acad. Sci. USA, 102, 5326-5333, 2005.

Raatikainen, T., Brus, D., Hyvärinen, A.-P., Svensson, J., Asmi, E., and Lihavainen, H.: Black carbon concentrations and mixing state in the Finnish Arctic, Atmos. Chem. Phys., 15, $10057-$ 10070, https://doi.org/10.5194/acp-15-10057-2015, 2015.

Raatikainen, T., Brus, D., Hooda, R. K., Hyvärinen, A.-P., Asmi, E., Sharma, V. P., Arola, A., and Lihavainen, H.: Size-selected black carbon mass distributions and mixing state in polluted and clean environments of northern India, Atmos. Chem. Phys., 17, 371-383, https://doi.org/10.5194/acp-17-371-2017, 2017.

Reddington, C. L., McMeeking, G., Mann, G. W., Coe, H., Frontoso, M. G., Liu, D., Flynn, M., Spracklen, D. V., and Carslaw, K. S.: The mass and number size distributions of black carbon aerosol over Europe, Atmos. Chem. Phys., 13, 4917-4939, https://doi.org/10.5194/acp-13-4917-2013, 2013.

Sahu, L. K., Kondo, Y., Moteki, N., Takegawa, N., Zhao, Y., Cubison, M. J., Jimenez, J. L., Vay, S., Diskin, G. S., Wisthaler, A., Mikoviny, T., Huey, L. G., Weinheimer, A. J., and Knapp, D. J.: Emission characteristics of black carbon in anthropogenic and solid fuel burning plumes over California during ARCTAS-CARB 2008, J. Geophys. Res., 117, D16302, https://doi.org/10.1029/2011JD017401, 2012.

Schnaiter, M., Linke, C., Möhler, O., Naumann, K. H., Saathoff, H., Wagner, R., Schurath, U., and Wehner, B.: Absorption amplification of black carbon internally mixed with 
secondary organic aerosol, J. Geophys. Res., 110, D19204, https://doi.org/10.1029/2005JD006046, 2005.

Schnitzler, E. G., Gac, J. M., and Jäger, W.: Coating surface tension dependence of soot aggregate restructuring, J. Aerosol Sci., 106, 43-55, https://doi.org/10.1016/j.jaerosci.2017.01.005, 2017.

Schwarz, J. P., Gao, R. S., Spackman, J. R., Watts, L. A., Thomson, D. S., Fahey, D. W., Ryerson, T. B., Peischl, J., Holloway, J. S., Trainer, M., Frost, G. J., Baynard, T., Lack, D. A., de Gouw, J. A., Warneke, C., and Del Negro, L. A.: Measurement of the mixing state, mass, and optical size of individual black carbon particles in urban and biomass burning emissions, Geophys. Res. Lett., 35, L13810, https://doi.org/10.1029/2008GL033968, 2008.

Schwarz, J. P., Gao, R. S., Perring, A. E., Spackman, J. R., and Fahey, D. W.: Black carbon aerosol size in snow, Sci. Rep., 3, 1356, https://doi.org/10.1038/srep01356, 2013.

Sedlacek III, A. J., Lewis, E. R., Kleinman, L., Xu, J., and Zhang, Q. Determination of and evidence for noncore-shell structure of particles containing black carbon using the Single-Particle Soot Photometer (SP2), Geophys. Res. Lett., 39, L06802, https://doi.org/10.1029/2012GL050905, 2012.

Sedlacek III, A. J., Onasch, T. B., Nichman, L., Lewis, E. R., Davidovits, P., Freedman, A., and Williams, L.: Formation of refractory black carbon by SP2-induced charring of organic aerosol, Aerosol Sci. Technol., 52, 1345-1350, https://doi.org/10.1080/02786826.2018.1531107, 2018.

Shank, L. M., Howell, S., Clarke, A. D., Freitag, S., Brekhovskikh, V., Kapustin, V., McNaughton, C., Campos, T., and Wood, R.: Organic matter and non-refractory aerosol over the remote Southeast Pacific: oceanic and combustion sources, Atmos. Chem. Phys., 12, 557-576, https://doi.org/10.5194/acp-12-5572012, 2012.

Sharma, S., Leaitch, W. R., Huang, L., Veber, D., Kolonjari, F., Zhang, W., Hanna, S. J., Bertram, A. K., and Ogren, J. A.: An evaluation of three methods for measuring black carbon in Alert, Canada, Atmos. Chem. Phys., 17, 15225-15243, https://doi.org/10.5194/acp-17-15225-2017, 2017.

Shiraiwa, M., Kondo, Y., Moteki, N., Takegawa, N., Miyazaki, Y., and Blake, D. R.: Evolution of mixing state of black carbon in polluted air from Tokyo, Geophys. Res. Lett., 34, L16803, https://doi.org/10.1029/2007GL029819, 2007.

Shiraiwa, M., Kondo, Y., Moteki, N., Takegawa, N., Sahu, L. K., Takami, A., Hatakeyama, S., Yonemura, S., and Blake, D. R.: Radiative impact of mixing state of black carbon aerosol in Asian outflow, J. Geophys. Res., 113, D24210, https://doi.org/10.1029/2008jd010546, 2008.

Shiraiwa, M., Kondo, Y., Iwamoto, T., and Kita, K.: Amplification of light absorption of black carbon by organic coating, Aerosol Sci. Tech., 44, 46-54, 2010.

Slowik, J. G., Cross, E. S., Han, J.-H., Davidovits, P., Onasch, T. B., Jayne, J. T., Williams, L. R., Canagaratna, M. R., Worsnop, D. R., Chakrabarty, R. K., Moosmueller, H., Arnott, W. P., Schwarz, J. P., Gao, R.-S., Fahey, D. W., Kok, G. L., and Petzold, A.: An inter-comparison of instruments measuring black carbon content of soot particles, Aerosol Sci. Tech., 41, 295-314, https://doi.org/10.1080/02786820701197078, 2007a.

Slowik, J. G., Cross, E. S., Han, J.-H., Kolucki, J., Davidovits, P., Williams, L. R., Onasch, T. B., Jayne, J. T., Kolb, C. E., and Worsnop, D. R.: Measurements of morphology changes of fractal soot particles using coating and denuding experiments: Implications for optical absorption and atmospheric lifetime, Aerosol Sci. Tech., 41, 734-750, https://doi.org/10.1080/02786820701432632, 2007b.

Srinivas, B. and Sarin, M. M.: $\mathrm{PM}_{2.5}$, EC and OC in atmospheric outflow from the Indo-Gangetic Plain: Temporal variability and aerosol organic carbon-to-organic mass conversion factor, Sci. Total Environ., 487, 196-205, https://doi.org/10.1016/j.scitotenv.2014.04.002, 2014.

Srivastava, R. and Ramachandran, S.: The mixing state of aerosols over the Indo-Gangetic Plain and its impact on radiative forcing, Q. J. Roy. Meteor. Soc., 139, 137-151. https://doi.org/10.1002/qj.1958, 2013.

Sun, Y., Wang, Z., Dong, H., Yang, T., Li, J., Pan, X., Chen, P., and Jayne, T. P.: Characterization of Summer Organic and Inorganic Aerosols in Beijing, China with an Aerosol Chemical Speciation Monitor, Atmos. Environ., 51, 250-259, https://doi.org/10.1016/j.atmosenv.2012.01.013, 2012.

Taylor, J. W., Allan, J. D., Liu, D., Flynn, M., Weber, R., Zhang, X., Lefer, B. L., Grossberg, N., Flynn, J., and Coe, H.: Assessment of the sensitivity of core / shell parameters derived using the singleparticle soot photometer to density and refractive index, Atmos. Meas. Tech., 8, 1701-1718, https://doi.org/10.5194/amt-8-17012015, 2015.

Taylor, J. W., Wu, H., Szpek, K., Bower, K., Crawford, I., Flynn, M. J., Williams, P. I., Dorsey, J., Langridge, J. M., Cotterell, M. I., Fox, C., Davies, N. W., Haywood, J. M., and Coe, H.: Absorption closure in highly aged biomass burning smoke, Atmos. Chem. Phys., 20, 11201-11221, https://doi.org/10.5194/acp-20-112012020, 2020.

Thamban, N. M., Tripathi, S. N., Shamjad P. M., Kuntamukkala, P., and Kanawade, V. P.: Internally mixed black carbon in the Indo-Gangetic Plain and its effect on absorption enhancement, Atmos. Res., 197, 211-223, https://doi.org/10.1016/j.atmosres.2017.07.007, 2017.

Ueda, S., Nakayama, T., Taketani, F., Adachi, K., Matsuki, A., Iwamoto, Y., Sadanaga, Y., and Matsumi, Y.: Light absorption and morphological properties of soot-containing aerosols observed at an East Asian outflow site, Noto Peninsula, Japan, Atmos. Chem. Phys., 16, 2525-2541, https://doi.org/10.5194/acp16-2525-2016, 2016.

Ueda, S., Osada, K., Hara, K., Yabuki, M., Hashihama, F., and Kanda, J.: Morphological features and mixing states of sootcontaining particles in the marine boundary layer over the Indian and Southern oceans, Atmos. Chem. Phys., 18, 9207-9224, https://doi.org/10.5194/acp-18-9207-2018, 2018.

Unger, N., Shindell, D. T., Koch, D. M., and Streets D. G.: Cross Influences of Ozone and Sulfate Precursor Emissions Changes on Air Quality and Climate, PNAS, 103, 4377-4380, 2006.

Wang, J., Liu, D., Ge, X., Wu, Y., Shen, F., Chen, M., Zhao, J., Xie, C., Wang, Q., Xu, W., Zhang, J., Hu, J., Allan, J., Joshi, R., $\mathrm{Fu}, \mathrm{P}$., Coe, H., and Sun, Y.: Characterization of black carboncontaining fine particles in Beijing during wintertime, Atmos. Chem. Phys., 19, 447-458, https://doi.org/10.5194/acp-19-4472019, 2019.

Wang, Q., Cao, J., Han, Y., Tian, J., Zhu, C., Zhang, Y., Zhang, N., Shen, Z., Ni, H., Zhao, S., and Wu, J.: Sources and physicochemical characteristics of black carbon aerosol from the southeastern Tibetan Plateau: internal mixing enhances light absorption, At- 
mos. Chem. Phys., 18, 4639-4656, https://doi.org/10.5194/acp18-4639-2018, 2018.

Weingartner, E., Burtscher, H., and Baltensperger, U.: Growth and structural change of combustion aerosols at high relative humidity, Environ. Sci. Technol., 29, 2982-2986, https://doi.org/10.1021/es00012a014, 1995.

Wiedensohler, A.: An approximation of the bipolar charge distribution for particles in the submicron size range, J. Aerosol Sci., 19, 387-389, 1988.

Xu, W., Croteau, P., Williams, L., Canagaratna, M., Onasch, T., Cross, E., Zhang, X., Robinson, W., Worsnop, D., and Jayne, J.: Laboratory characterization of an aerosol chemical speciation monitor with $\mathrm{PM}_{2.5}$ measurement capability, Aerosol Sci. Tech., 51, 69-83, https://doi.org/10.1080/02786826.2016.1241859, 2017.

Xue, H. X., Khalizov, A. F., Wang, L., Zheng, J., and Zhang, R. Y.: Effects of Coating of Dicarboxylic Acids on the Mass-Mobility Relationship of Soot Particles, Environ. Sci. Technol., 43, 27872792, https://doi.org/10.1021/es803287v, 2009.

Zanatta, M., Laj, P., Gysel, M., Baltensperger, U., Vratolis, S., Eleftheriadis, K., Kondo, Y., Dubuisson, P., Winiarek, V., Kazadzis, S., Tunved, P., and Jacobi, H.-W.: Effects of mixing state on optical and radiative properties of black carbon in the European Arctic, Atmos. Chem. Phys., 18, 14037-14057, https://doi.org/10.5194/acp-18-14037-2018, 2018.
Zhang, J., Liu, J., Tao, S., and Ban-Weiss, G. A.: Long-range transport of black carbon to the Pacific Ocean and its dependence on aging timescale, Atmos. Chem. Phys., 15, 11521-11535, https://doi.org/10.5194/acp-15-11521-2015, 2015.

Zhang, R., Khalizov, A. F., Pagels, J., Zhang, D., Xue, H., and McMurry, P. H.: Variability in morphology, hygroscopicity, and optical properties of soot aerosols during atmospheric processing, P. Natl. Acad. Sci. USA, 105, 10291-10296, https://doi.org/10.1073/pnas.0804860105, 2008.

Zhang, Y., Zhang, Q., Cheng, Y., Su, H., Kecorius, S., Wang, Z., Wu, Z., Hu, M., Zhu, T., Wiedensohler, A., and He, K.: Measuring the morphology and density of internally mixed black carbon with SP2 and VTDMA: new insight into the absorption enhancement of black carbon in the atmosphere, Atmos. Meas. Tech., 9, 1833-1843, https://doi.org/10.5194/amt-9-1833-2016, 2016.

Zorn, S. R., Drewnick, F., Schott, M., Hoffmann, T., and Borrmann, S.: Characterization of the South Atlantic marine boundary layer aerosol using an aerodyne aerosol mass spectrometer, Atmos. Chem. Phys., 8, 4711-4728, https://doi.org/10.5194/acp-8-47112008, 2008. 